\title{
Insights into the Host Specificity of a New Oomycete Root Pathogen, Pythium brassicum P1: Whole Genome Sequencing and Comparative Analysis Reveals Contracted Regulation of Metabolism, Protein Families, and Distinct Pathogenicity Repertoire
}

\author{
Mojtaba Mohammadi ${ }^{1,+}$, Eric A. Smith ${ }^{1,+}{ }^{,}$Michael E. Stanghellini ${ }^{1}$ and Rakesh Kaundal ${ }^{2,3, * \text { D }}$ \\ 1 Department of Microbiology and Plant Pathology, University of California, 900 University Ave., \\ Riverside, CA 92521, USA; mojtaba.mohammadi@usda.gov (M.M.); eas10@iu.edu (E.A.S.); \\ mstang@ucr.edu (M.E.S.) \\ 2 Department of Plants, Soils, and Climate, College of Agriculture and Applied Sciences, Utah State University, \\ 4820 Old Main Hill, Logan, UT 84322, USA \\ 3 Bioinformatics Facility, Center for Integrated BioSystems, College of Agriculture and Applied Sciences, \\ Utah State University, 4700 Old Main Hill, Logan, UT 84322, USA \\ check for \\ updates \\ * Correspondence: rkaundal@usu.edu; Tel.: +1-(435)-797-4117; Fax: +1-(435)-797-2766 \\ + Denotes equal contributions.
}

Citation: Mohammadi, M.; Smith, E.A.; Stanghellini, M.E.; Kaundal, R Insights into the Host Specificity of a New Oomycete Root Pathogen, Pythium brassicum P1: Whole Genome Sequencing and Comparative Analysis Reveals Contracted Regulation of Metabolism, Protein Families, and Distinct Pathogenicity Repertoire. Int. J. Mol. Sci. 2021, 22, 9002. https://doi.org/10.3390/ ijms22169002

Academic Editor: Setsuko Komatsu

Received: 14 July 2021

Accepted: 16 August 2021

Published: 20 August 2021

Publisher's Note: MDPI stays neutral with regard to jurisdictional claims in published maps and institutional affiliations.

Copyright: (c) 2021 by the authors. Licensee MDPI, Basel, Switzerland This article is an open access article distributed under the terms and conditions of the Creative Commons Attribution (CC BY) license (https:// creativecommons.org/licenses/by/ $4.0 /)$.
Abstract: Pythium brassicum P1 Stanghellini, Mohammadi, Förster, and Adaskaveg is an oomycete root pathogen that has recently been characterized. It only attacks plant species belonging to Brassicaceae family, causing root necrosis, stunting, and yield loss. Since P. brassicum P1 is limited in its host range, this prompted us to sequence its whole genome and compare it to those of broad host range Pythium spp. such as P. aphanidermatum and P. ultimum var. ultimum. A genomic DNA library was constructed with a total of 374 million reads. The sequencing data were assembled using SOAPdenovo2, yielding a total genome size of $50.3 \mathrm{Mb}$ contained in 5434 scaffolds, N50 of $30.2 \mathrm{~Kb}, 61.2 \% \mathrm{G}+\mathrm{C}$ content, and 13,232 putative protein-coding genes. Pythium brassicum $\mathrm{P} 1 \mathrm{had}$ 175 species-specific gene families, which is slightly below the normal average. Like P. ultimum, P. brassicum P1 genome did not encode any classical RxLR effectors or cutinases, suggesting a significant difference in virulence mechanisms compared to other oomycetes. Pythium brassicum P1 had a much smaller proportions of the YxSL sequence motif in both secreted and non-secreted proteins, relative to other Pythium species. Similarly, P. brassicum P1 had the fewest Crinkler (CRN) effectors of all the Pythium species. There were 633 proteins predicted to be secreted in the P. brassicum P1 genome, which is, again, slightly below average among Pythium genomes. Pythium brassicum P1 had only one cadherin gene with calcium ion-binding LDRE and DxND motifs, compared to Pythium ultimum having four copies. Pythium brassicum P1 had a reduced number of proteins falling under carbohydrate binding module and hydrolytic enzymes. Pythium brassicum P1 had a reduced complement of cellulase and pectinase genes in contrast to P. ultimum and was deficient in xylan degrading enzymes. The contraction in ABC transporter families in P. brassicum P1 is suggested to be the result of a lack of diversity in nutrient uptake and therefore host range.

Keywords: Pythium brassicum; Brassicaceae; whole genome sequence; host-specific mechanisms; root pathogen; comparative genomics; oomycete

\section{Introduction}

Pythium spp. belong to oomycetes, a diverse group of fungal-like organisms that are members of the non-photosynthetic Staminipila and closely related to aquatic organisms such as brown algae and diatoms [1]. Within the genus Pythium, there are as many as 
355 described species [2], of which 116 species and varieties are classified into 11 phylogenetic clades, designated as Clades A-K, based on internal transcribed spacer (ITS) region of the nuclear ribosomal DNA [3]. The majority of Pythium species are ubiquitous, soilborne, saprophytic, or facultative necrotrophic root pathogens, causing a wide range of diseases such as stem rots and damping-off, root, stem, and fruit rots, leaf blights, and postharvest decay [4]. They are considered preclinical opportunistic necrotrophs that attack crop species at the seedling stage or under stress [5].

Pythium species are genetically diverse and significantly distinct with respect to host range, virulence, and geographical distribution [4-7]. For instance, Pythium aphanidermatum has a broad host range, is extremely virulent, and is a high temperature root pathogen that occurs routinely under greenhouse conditions, whereas Pythium arrhenomanes is more restricted to monocots. On the other hand, both Pythium ultimum var. ultimum and Pythium irregulare are highly virulent at cooler temperatures, with broad host range and genetic and morphological diversities. Pythium iwayamai is another cool temperature species and causes snow rot on economically important monocots such as barley and winter wheat [8]. Pythium species that belong to clade $\mathrm{K}$ are phylogenetically distinct from the rest of Pythium spp. and are reported to exhibit characteristics shared by both Pythium and Phytophthora, and are therefore named Phytopythium [9]. One such example is Phytopythium vexans, which causes root rot in many tropical plants, including durian [10] and rubber tree [11].

To this date, as many as eleven species of Pythium have been sequenced using next-generation sequencing platforms. These include P. aphanidermatum, P. arrhenomanes, P. guiyangense, P. insidiosum, P. irregulare, P. iwayamai, P. oligandrum, P. periplocum, P. splendens, P. ultimum var. sporangiiferum, and P. ultimum var. ultimum [12-15]. Recent comparative genome analyses have revealed a significant reduction in genome size (genes involved in infection process) in P. ultimum var. ultimum compared to Phytophthora species [12,15].

Pythium brassicum Stanghellini, Mohammadi, Förster, and Adaskaveg is an oomycete root pathogen that has recently been characterized based on morphology, host range, and molecular phylogeny [16]. Unlike other Pythium spp., P. brassicum P1 has a narrow host range and only attacks roots of vegetable crops belonging to the Brassicaceae family, thereby causing root rot, stunting, and yield loss.

The main objectives in this study were to investigate how genetically different $P$. brassicum P1 is from broad host range Pythium spp. and to understand its pathogenicity mechanisms based on the complete genome sequence analysis and comparative genomics.

\section{Results and Discussion}

\subsection{Genome Sequencing, Assembly, and Annotation}

Sequencing was carried out on the Illumina HiSeq 2500, generating a total of $374 \mathrm{mil}-$ lion, $1 \times 100 \mathrm{bp}$ reads, resulting in 37.4 gigabases of sequence data; $91.4 \%$ of bases had a quality score $\geq$ Q30. An initial SOAPdenovo2 [17] assembly was generated and reassembled using CAP3 [18]. This assembly was $50.3 \mathrm{Mb}$, spread among 5434 scaffolds, with a N50 scaffold length of $30.2 \mathrm{~Kb}$, a N90 scaffold length of $6892 \mathrm{bp}$, and GC content of $61.2 \%$ (Tables 1 and 2). The P. brassicum P1 genome was larger and had a higher GC content than P. ultimum (genome size: $42.8 \mathrm{Mb}, 52.3 \% \mathrm{G}+\mathrm{C}$ content) [19]. The quality of the complete assembled genome was examined using QUAST (Figure 1). The MAKER annotation pipeline [20] predicted 13,232 genes in the P. brassicum P1 genome, which fell within the range of previously published Pythium genomes. The completeness of the P. brassicum P1 was evaluated using BUSCO [21]; P. brassicum P1 was missing 27 of 429 $(\sim 6 \%)$ eukaryotic universal single-copy orthologs, which was again within the range of previously published Pythium genomes (genomes downloaded from the Pythium Genome Database, and BUSCO scores were determined as with P. brassicum P1). RepeatScout [22] identified 49,717 unclassified repeat sequences in the genome, representing $23.35 \%$ of the total genomic sequence. Both the total number of repeats and the percentage of the genome contained in repeat sequence were much higher in P. brassicum P1 than P. ultimum, but considerably lower than Phytophthora infestans [23]; interestingly, genome size and 
GC content in P. brassicum P1 also represented an intermediate between P. ultimum and Ph. infestans.

a

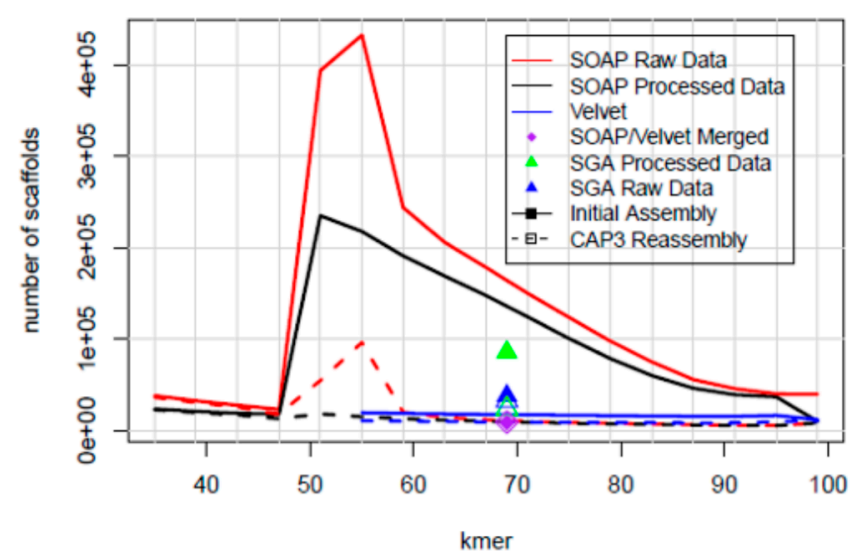

C

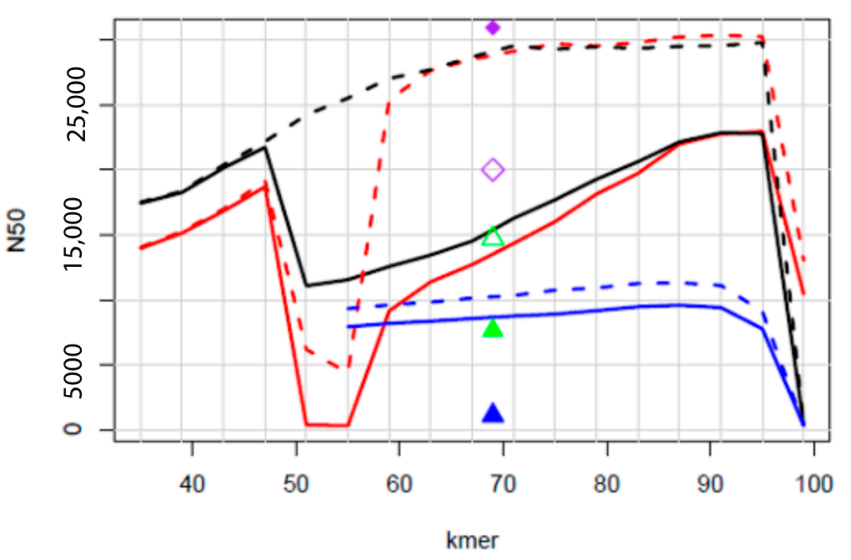

b Maximum Scaffold Length

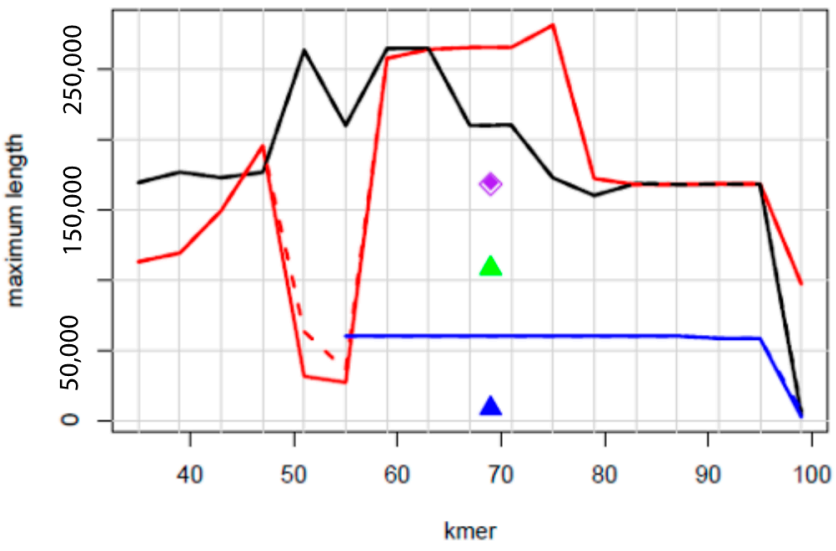

d

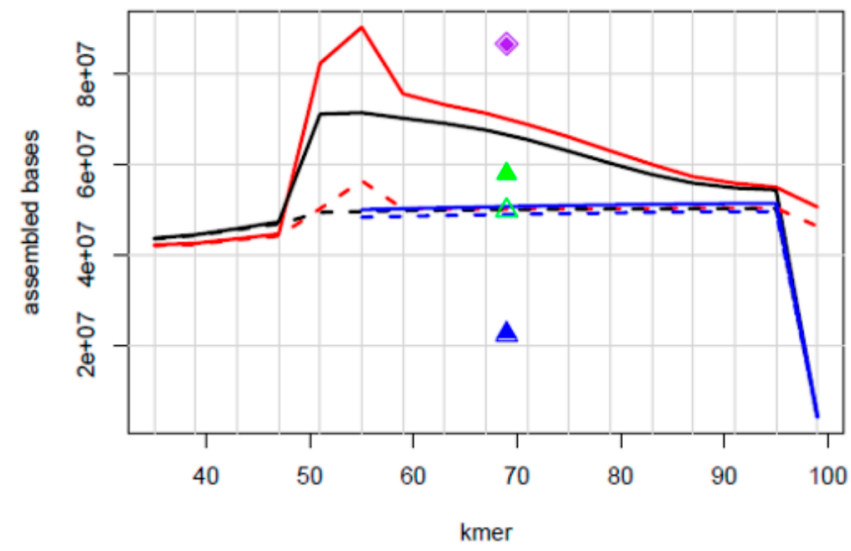

Figure 1. Plots representing total scaffolds (a), maximum scaffold length (b), N50 statistics (c), and assembly size (d) of P. brassicum P1 genome. The quality of the completed assembled genome was performed using QUAST.

Table 1. Number of contigs (a), cumulative length (b), and GC content (c) of P. brassicum P1 isolate in merged assembly, merged reassembly, sga processed data, sga raw data, soap processed data, soap raw data, and velvet processed data.

\begin{tabular}{|c|c|c|c|c|c|c|c|}
\hline & $\begin{array}{l}\text { Merged } \\
\text { Assembly }\end{array}$ & $\begin{array}{c}\text { Merged } \\
\text { Reassembly }\end{array}$ & $\begin{array}{c}\text { Sga_Processed } \\
\text { Data }\end{array}$ & $\underset{\text { Data }}{\text { Sga_Raw }}$ & $\begin{array}{c}\text { Soap_Processed } \\
\text { Data }\end{array}$ & $\begin{array}{c}\text { Soap_Raw } \\
\text { Data }\end{array}$ & $\begin{array}{c}\text { Velvet_Processed } \\
\text { Data }\end{array}$ \\
\hline$\#$ contigs $(\geq 0 \mathrm{bp})^{\mathrm{a}}$ & 8759 & 9191 & 23,698 & 32,489 & 5437 & 5434 & 8420 \\
\hline \# contigs $(\geq 1000 \mathrm{bp})$ & 4917 & 7631 & 5413 & 6977 & 3161 & 3074 & 6690 \\
\hline \# contigs $(\geq 5000 \mathrm{bp})$ & 3454 & 4468 & 2336 & 36 & 2052 & 2020 & 3302 \\
\hline \# contigs $(\geq 10,000 \mathrm{bp})$ & 2594 & 2661 & 1391 & 0 & 1468 & 1456 & 1569 \\
\hline \# contigs $(>250,000 \mathrm{bp})$ & 1161 & 852 & 420 & 0 & 624 & 631 & 207 \\
\hline \# contigs $(\geq 50,000 \mathrm{bp})$ & 300 & 190 & 48 & 0 & 179 & 184 & 4 \\
\hline Total length $(\geq 0 \mathrm{bp})^{\mathrm{b}}$ & $86,486,191$ & $86,588,769$ & $49,749,428$ & $22,192,922$ & $50,166,055$ & $50,256,276$ & $49,506,384$ \\
\hline Total length $(\geq 1000 \mathrm{bp})$ & $85,411,003$ & $85,824,021$ & $44,743,758$ & $12,211,453$ & $49,404,430$ & $49,485,932$ & $48,588,674$ \\
\hline Total length ( $\geq 5000 \mathrm{bp})$ & $81,590,182$ & $77,200,690$ & $37,494,792$ & 210,549 & $46,532,065$ & $46,759,275$ & $39,463,530$ \\
\hline Total length $(\geq 10,000 \mathrm{bp})$ & $75,284,912$ & $64,184,486$ & $30,706,745$ & 0 & $42,312,012$ & $42,673,554$ & $27,132,574$ \\
\hline Total length $(\geq 25,000 \mathrm{bp})$ & $51,913,458$ & $35,988,051$ & $15,559,417$ & 0 & $28,470,025$ & $29,136,472$ & $6,563,575$ \\
\hline Total length $(\geq 50,000 \mathrm{bp})$ & $21,977,981$ & $13,602,359$ & $2,999,251$ & 0 & $12,999,233$ & $13,636,629$ & 219,978 \\
\hline
\end{tabular}


Table 1. Cont

\begin{tabular}{|c|c|c|c|c|c|c|c|}
\hline & $\begin{array}{l}\text { Merged } \\
\text { Assembly }\end{array}$ & $\begin{array}{c}\text { Merged } \\
\text { Reassembly }\end{array}$ & $\begin{array}{c}\text { Sga_Processed } \\
\text { Data }\end{array}$ & $\underset{\text { Data }}{\text { Sga_Raw }}$ & $\begin{array}{c}\text { Soap_Processed } \\
\text { Data }\end{array}$ & $\begin{array}{c}\text { Soap_Raw } \\
\text { Data }\end{array}$ & $\begin{array}{c}\text { Velvet_Processed } \\
\text { Data }\end{array}$ \\
\hline \# contigs & 5514 & 8341 & 7482 & 14,369 & 3629 & 3525 & 7543 \\
\hline Largest contig & 169,369 & 168,160 & 108,107 & 8673 & 168,160 & 168,309 & 58,392 \\
\hline Total length & $85,839,345$ & $86,347,227$ & $46,193,713$ & $17,504,468$ & $49,739,698$ & $49,811,232$ & $49,223,359$ \\
\hline $\mathrm{GC}(\%)^{\mathrm{c}}$ & 59.81 & 59.63 & 59.95 & 59.94 & 59.59 & 59.61 & 59.59 \\
\hline N50 & 31,156 & 20,060 & 16,383 & 1400 & 30,050 & 30,476 & 11,201 \\
\hline N75 & 16,898 & 9789 & 7080 & 907 & 15,561 & 15,907 & 5942 \\
\hline L50 & 841 & 1176 & 799 & 4050 & 493 & 478 & 1330 \\
\hline L75 & 1772 & 2720 & 1860 & 7938 & 1073 & 1044 & 2837 \\
\hline \# N's per $100 \mathrm{~kb}$ & 1386.58 & 345.10 & 2036.02 & 4612.90 & 613.35 & 560.43 & 0.00 \\
\hline predicted genes (unique) & 24,973 & 26,049 & 12,908 & - & 14,305 & 14,423 & - \\
\hline $\begin{array}{l}\text { \# predicted genes } \\
(\geq 0 \mathrm{bp})\end{array}$ & 88,235 & 90,798 & 59,287 & - & 52,918 & 51,696 & - \\
\hline $\begin{array}{l}\text { \# predicted genes } \\
(\geq 300 \mathrm{bp})\end{array}$ & 31,133 & 32,154 & 18,350 & - & 18,234 & 17,990 & - \\
\hline $\begin{array}{l}\text { \# predicted genes } \\
(\geq 1500 \mathrm{bp})\end{array}$ & 5790 & 5744 & 1714 & - & 3191 & 3321 & - \\
\hline $\begin{array}{l}\text { \# predicted genes } \\
(\geq 3000 \mathrm{bp})\end{array}$ & 1383 & 1271 & 209 & - & 703 & 789 & - \\
\hline
\end{tabular}

All statistics are based on contigs of size $\geq 500 \mathrm{bp}$, unless otherwise noted (e.g., "\# contigs ( $\geq 0 \mathrm{bp})$ " and "Total length ( $\geq 0$ bp)" include all contigs).

Table 2. Pythium brassicum assembled genome statistics.

\begin{tabular}{lcc}
\hline & Scaffolds & Contigs \\
\hline Number of sequences & 5434 & 64,712 \\
Maximum sequence length (bp) & 168,309 & 56,387 \\
Average length (bp) & 9248.49 & 879.7 \\
N50(bp) & 30,235 & 6705 \\
N90 (bp) & 6892 & 207 \\
Sequences > 500 bp & & \\
Number of sequences & 3525 & 11,344 \\
Average length (bp) & $14,130.85$ & 4279.21 \\
N50(bp) & 30,476 & 8290 \\
N90 (bp) & 7473 & 1811 \\
Sequences > $\mathbf{~ K b}$ & & \\
Number of sequences & 3074 & 8364 \\
Average length (bp) & $16,098.22$ & 5551.03 \\
N50(bp) & 30,985 & 8732 \\
N90 (bp) & 7803 & 2396 \\
Sequences > 5 Kb & & \\
Number of sequences & 2020 & 3090 \\
Average length (bp) & $23,148.16$ & $10,840.34$ \\
N50(bp) & 33,000 & 12,061 \\
N90 (bp) & 10,751 & 6102 \\
Sequences > 10 Kb & & \\
Number of sequences & 1456 & 1273 \\
Average length (bp) & $29,308.76$ & $16,327.77$ \\
N50(bp) & 35,695 & 11,104 \\
N90 (bp) & 14,907 & \\
Total number of assembled bases & $50,256,276$ & \\
\hline
\end{tabular}

\subsection{Annotation of Predicted Proteins}

For annotation, the P. brassicum P1 assembled sequences were searched against the NCBI non-redundant protein database (NR) with a cut-off E-value of $1 \times 10^{-6}$. There were $>30,000$ BLAST hits that met this E-value cut-off threshold, indicating that, on average, a predicted gene had $\sim 3$ BLAST hits; this provides a robust basis for Gene Ontology (GO) term prediction (see Section 2.3). The most abundant species hit was Phytophthora parasitica, another oomycete plant pathogen (Supplementary Figure S1). The majority of hits had 60\% positive matches over the length of the alignment. 


\subsection{Classification of Gene Ontology (GO)}

We used the program Blast2GO [24] to convert our BLAST results into GO term annotations. In total, there were 3746 genes annotated in the biological process category, 3033 in the cellular component category, and 3895 in the molecular function category (Figure 2). In the biological process category (Supplementary Figures S2 and S3), the most prominent level 3 GO annotations were cellular metabolic process, organic substance metabolic process, primary metabolic process, single-organism cellular process, and nitrogen compound metabolic process. These processes could all, ostensibly, serve important roles in the pathogenicity of $P$. brassicum, particularly organic substance metabolic processes and nitrogen compound metabolic processes, as these are important components of plant health. In the cellular component category (Supplementary Figures S4 and S5), the most prominent level 3 annotations were intracellular, intracellular part, intracellular organelle, membrane-bound organelle, and intrinsic component of membrane. Intracellular and membrane components may play roles in how P. brassicum interacts with its plant hosts, and these genes provide interesting avenues for additional study. In the molecular function category (Supplementary Figures S6 and S7), the most abundant level 3 annotations were heterocyclic compound binding, organic cyclic compound binding, ion binding, hydrolase activity, and transferase activity. Ion binding functions and hydrolase functions have the potential to contribute to plant pathogenicity in P. brassicum, as ions are important intracellular signals and could be used by P. brassicum as a means of interfering with normal plant biology; hydrolases may be used by P. brassicum to break cell wall bonds and infiltrate plant cells.

\subsection{Over- and Under-Represented Gene Families}

We used two methods to determine which gene families were over- or under-represented in the P. brassicum P1 genome relative to closely related species. The first method was a comparison of the genome content P. brassicum P1 and P. ultimum var. ultimum using the PANTHER database (pantherdb.org). This analysis uses a Fisher's exact test with false discovery rate correction to determine significantly over- and under-represented PANTHER families in one genome relative to another. Interestingly, when we compared P. brassicum $\mathrm{P} 1$ to P. ultimum var. ultimum, there were no PANTHER families that were significantly over- or under-represented in either genome relative to the other. There were, however, several PANTHER GO-slim biological process families that were more than two-fold enriched in P. brassicum P1 relative to P. ultimum var. ultimum. These included: system process (3.07-fold enriched), neurological system process (3.07-fold enriched), cell growth (2.04-fold enriched), spermatogenesis (2.04-fold enriched), growth (2.04-fold enriched), gamete generation (2.04-fold enriched), and negative regulation of apoptotic process (2.04-fold enriched). It is interesting that the majority of enriched biological process categories in P. brassicum are ostensibly involved in cell growth and reproduction. These could be adaptations to increase spread throughout the host plant and between host plant specimens. As a specialist pathogen, it is feasible that $P$. brassicum has adapted to specialize in how it utilizes the nutrients available to it, and thus is able to reproduce and grow faster than closely-related generalist pathogens. In the PANTHER GO-slim molecular function category, there were two families that were greater than two-fold enriched in P. brassicum P1: amino acid kinase activity and DNA-methyltransferase activity. Both of these categories may play roles in how P. brassicum communicates or interferes with communication of the host plant. There was only one PANTHER family that was greater than two-fold enriched in P. ultimum var. ultimum relative to P. brassicum P1 (e.g., under-represented in P. brassicum P1): ectoderm development. The second approach we took to determine overand under-represented gene families in P. brassicum P1 was CAFE, which uses a stochastic birth-death model across a phylogeny to determine which gene families are significantly expanding or contracting (relative to the ancestral state) on each branch of the phylogeny. Using this strategy, we were able to identify a number of expanding and contracting gene families in P. brassicum P1 (Table 3). Major expanding domain families included 
Ankyrin repeats, which play a role in protein-protein interaction; reverse transcriptase; a number of protein families involved in chromatin remodeling (e.g., SET domain proteins, chromatin organization modifier domain proteins, and centromere DNA binding proteins); and the integrase core domain, which is responsible for retroviral incorporation into the host genome. Major contracting families included a number of transporter or facilitator families, such as: $A B C$ transporters, major facilitator superfamily, transmembrane amino acid transporters, and sugar transporters. The contractions seen in transporter families in $P$. brassicum $\mathrm{P} 1$ may be the result of lacking diversity in nutrient uptake and therefore host range.

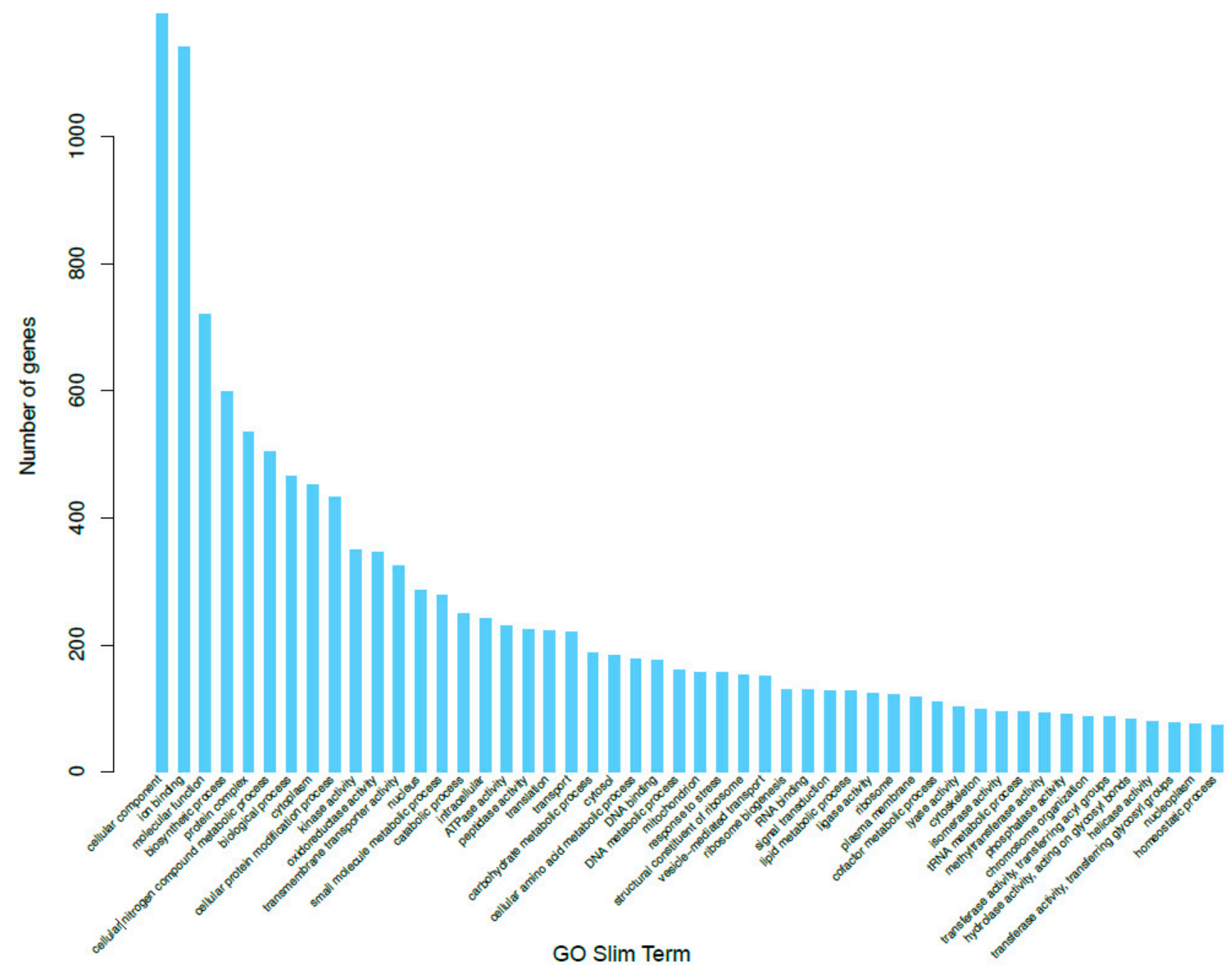

Figure 2. Gene Ontology (GO) distributions for P. brassicum P1 predicted genes for all 3 GO categories; Biological Process (BP), Molecular Function (MF), and Cellular Component (CC).

\subsection{Core and Species-Specific Gene Families}

We compared the genome content of P. brassicum P1 and seven other previously published Pythium genomes to identify species-specific gene clusters, as well as a core Pythium genome using OrthoMCL [25]. In general, Pythium species had genes contained in 9000 to $\sim 11,000$ gene clusters. The Pythium core genome contains a total of 5484 orthologous gene clusters, made up of 52,061 total proteins across the genus. Figure 3 shows a comparison of all Pythium species analyzed and the number of gene clusters and genes shared between species. Pythium brassicum had 175 species-specific gene clusters, which was slightly below average for the species used in this comparison. Secondly, we performed targeted analysis 
of the identified P. brassicum P1 proteome, for example analysis of the secretome, effectors, proteins involved in carbohydrate metabolism, etc.

Table 3. The number of proteins in Pythium brassicum P1 genome with a single copy ('Single hits') or multiple copies ('Multi hits') of domains involved in host plant disease development.

\begin{tabular}{lcc}
\hline Description & Multi_Hits & Single_Hits \\
\hline ABC transporter transmembrane region & 0 & 17 \\
Transmembrane amino acid transporter protein & 0 & 5 \\
ABC transporter & 0 & 5 \\
Major facilitator superfamily & 0 & 4 \\
Sugar (and other) transporter & 0 & 4 \\
Sulfatase & 0 & 2 \\
Alcohol dehydrogenase GroES-like domain & 0 & 2 \\
Zinc Binding dehydrogenase & 0 & 2 \\
AMP-binding enzyme & 0 & 1 \\
Uncharacterized protein family UPF0565 & 0 & 1 \\
RecF/RecN/SMC N terminal domain & 0 & 1 \\
HECT-domain (ubiquitin-transferase) & 0 & 1 \\
Putative transposase DNA-binding domain & 0 & 1 \\
Tc5 transposase DNAbinding domain & 0 & 1 \\
AAA domain, putative AbiEii Toxin, type IV TA System & 0 & 1 \\
Reverse transcriptase-like & 0 & \\
\hline
\end{tabular}

\subsection{Secretome}

Using SignalP [26], we identified secreted proteins in the P. brassicum P1 genome. There are 633 proteins ( $4.78 \%$ of the proteome) that are predicted to be secreted in the P. brassicum P1 genome, which is, again, slightly below average among published Pythium genomes (genomes downloaded from the Pythium genome database and annotated for secreted genes using the same method as P. brassicum). Notable protein families in the P. brassicum P1 secretome included aspartyl proteases, cysteine proteases, cytochrome p450s, elicithinlike proteins, glycoside hydrolases, lipases, NPP1-like proteins, carbohydrate esterases, polysaccharide lyases, phospholipases, and protease inhibitors. The presence of so many proteinases in the secretome was not unexpected, given P. brassicum P1's role as a plant pathogen; many of these genes would be expected to play a role in this species' interactions with its host plants.

\section{7. $\mathrm{Ca}^{2+}$-Dependent Cadherins}

Cadherins are calcium ion-dependent transmembrane proteins that are involved in the formation of adherens junctions responsible for binding cells together [27]. Pythium ultimum had four cadherin genes with calcium ion-binding LDRE and DxND motifs [19]. In contrast, $P$. brassicum P1 contained only one cadherin gene in its genome. 


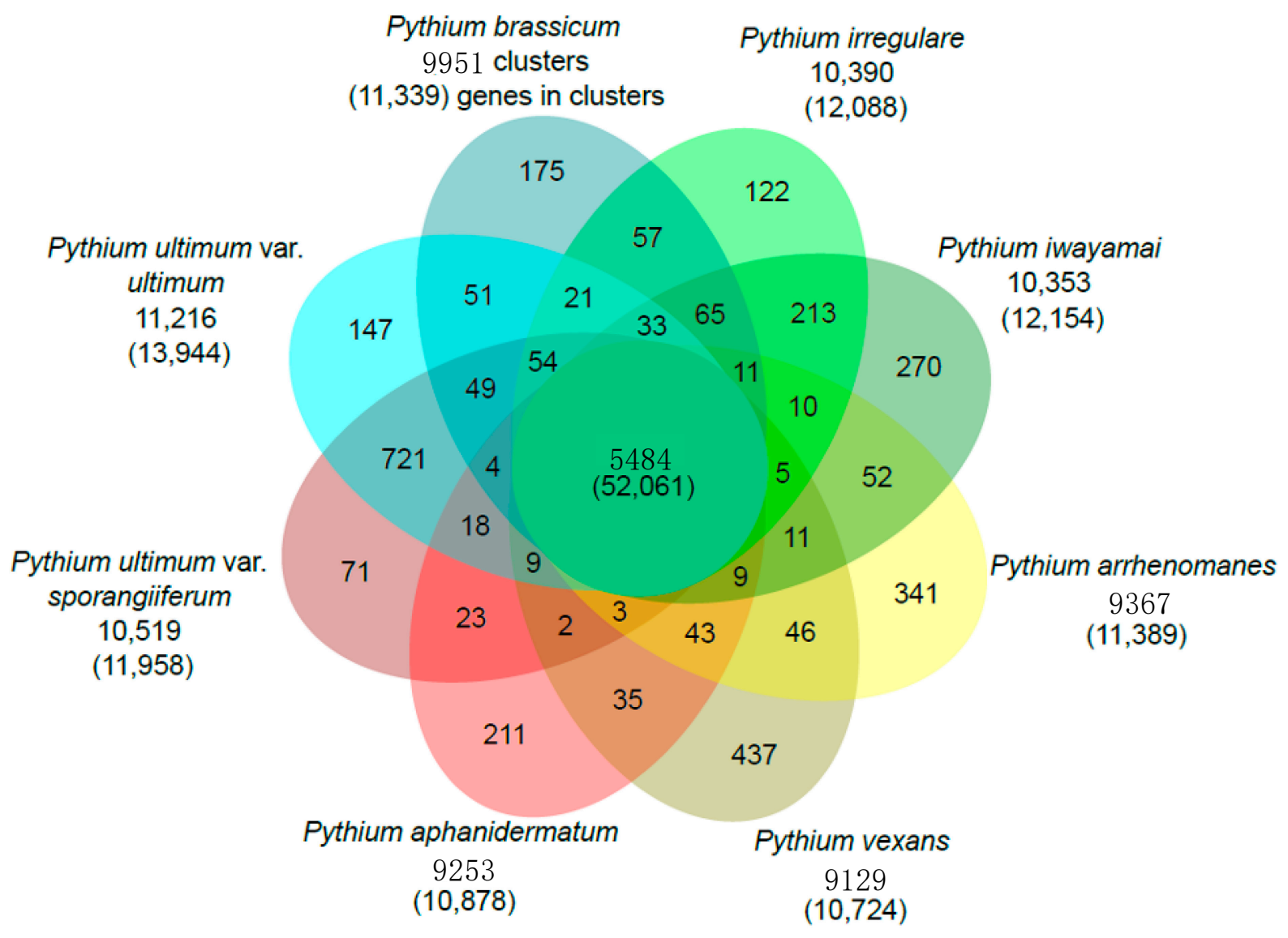

Figure 3. Venn diagram showing gene families shared by P. brassicum P1 and other Pythium species (i.e., P. ultimum var. ultimum and P. aphanidermatum).

\subsection{Effector Repertoire}

Using the predicted secreted proteins and an HMM search, we identified candidate effector proteins in previously identified classes (YxSL, CRN, and RxLR):

(i). YxSL[KR] effectors: P. brassicum $\mathrm{P} 1$ had much smaller proportions of the YxSL sequence motif in both secreted and non-secreted proteins, relative to other Pythium species. Pythium ultimum var. ultimum had the highest proportion of secreted proteins with YxSL motifs, while P. aphanidermatum had the highest proportion of non-secreted proteins with YxSL motifs. Pythium brassicum $\mathrm{P} 1$ had the lowest proportion of proteins with YxSL motifs in both secreted and non-secreted proteins (Figure 4a,b).

(ii). CRN effectors: The Crinkler ( $\mathrm{crn}$ ) gene family encodes a large class of secreted proteins that share a conserved amino-terminal LFLAK domain involved in host translocation in Phytophthora spp. [23]. As seen with YxSL effectors, Pythium brassicum P1 had the fewest CRN effectors of all the Pythium species (Figure 5).

a. LYLAR or LYLAK motifs: P. brassicum P1 was predicted to have three secreted proteins with the LYLA[R/K] motif, which was below the Pythium-wide average of 11.75 (Figure 5a). The genome was predicted to have 109 non-secreted proteins with the LYLA $[\mathrm{R} / \mathrm{K}]$ motif, again below the Pythium-wide average of 240.25 (Figure $5 b$ ).

b. LxLFLAK motif: We found no evidence for the LxFLAK motif in secreted proteins from any of the Pythium genomes, except for Pythium arrhenomanes, which had one (Figure 5c). There were similarly low numbers of non-secreted proteins in Pythium genomes with the LxLFLAK motif.

(iii). RxLR effectors: Consistent with previous studies, we found no evidence of RxLR virulent effectors in the P. brassicum P1 genome. This is in contrast to Phytophthora 
spp., which contain hundreds of RxLR genes in their genomes. These effector proteins are known to have an amino-terminal cell-entry domain with the RxLR and dEER motifs $[23,28]$ that mediate the entry of these effector proteins into host cells without requiring the presence of pathogen-encoded machinery [29]. The RxLR-dEER effectors are thought to be involved in manipulating host immunity and suppressing host defense responses, but a few are recognized by plant immune receptors, culminating in programmed cell death and disease resistance.

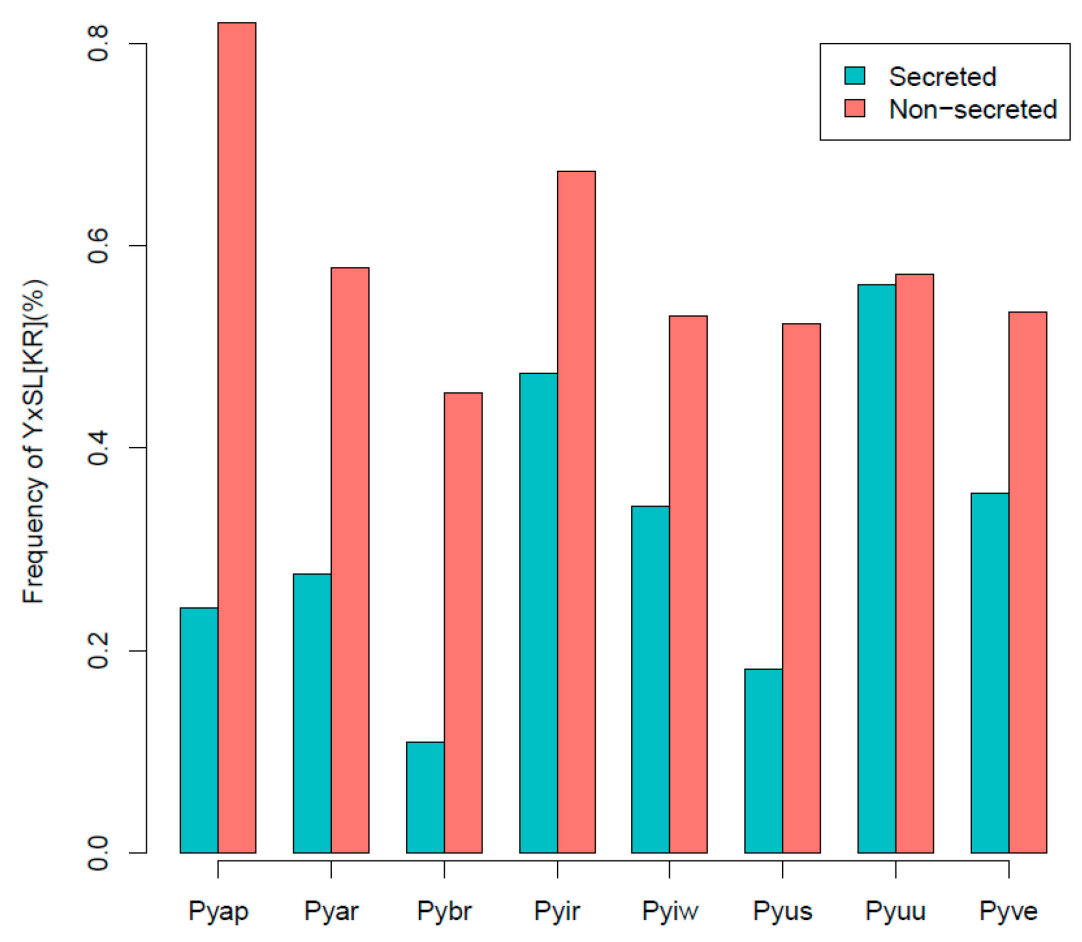

(a)
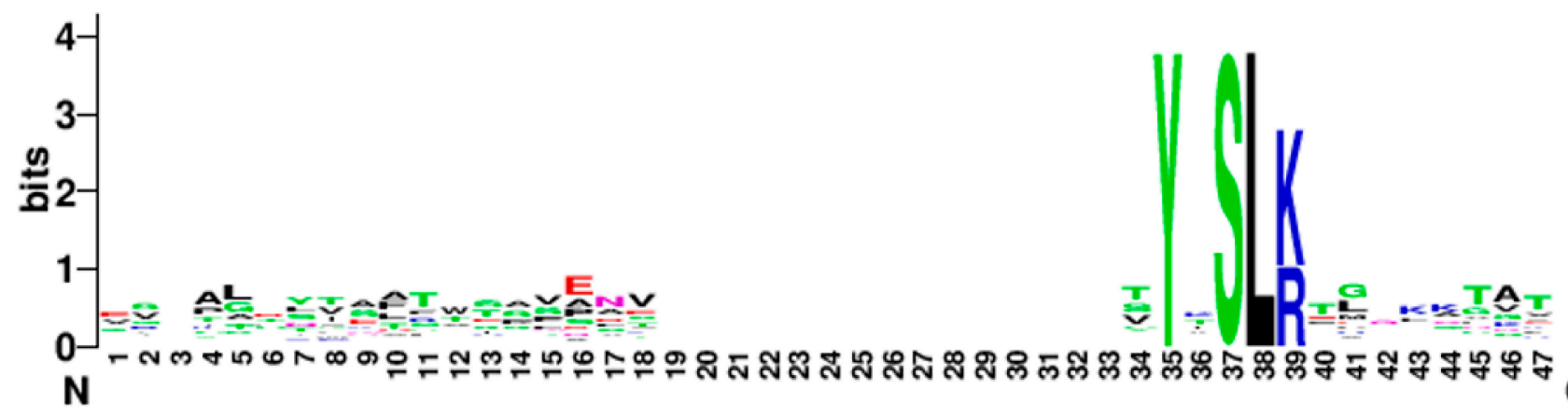

$\mathbf{N}$

(b)

Figure 4. Percentage frequency of secreted and non-secreted YxSL[RK] effector proteins in P. brassicum P1 (Pybr), P. aphanidermatum (Pyap), P. arrhenomanes (Pyar), P. irregulare (Pyir), P. iwayamai (Pyiw), P. ultimum var. sporangiiferum (Pyus), P. ultimum var. ultimum (Pyuu), and P. vexans (Pyve) (a), and the typical architecture of a YxSL(RK) effector candidate inferred from 51 Pythium YxSL(RK) protein motifs (b). The consensus sequence pattern of YxSL(RK) motif was computed using WebLogo (available online: http:/ / weblogo.berkeley.edu/logo.cgi) (accessed on 16 February 2021). The larger the letter, the more conserved the amino acid site. The numbers in the sequence logo refer to the corresponding positions in the alignment and thus differ from the average position of the motifs in the proteins. 


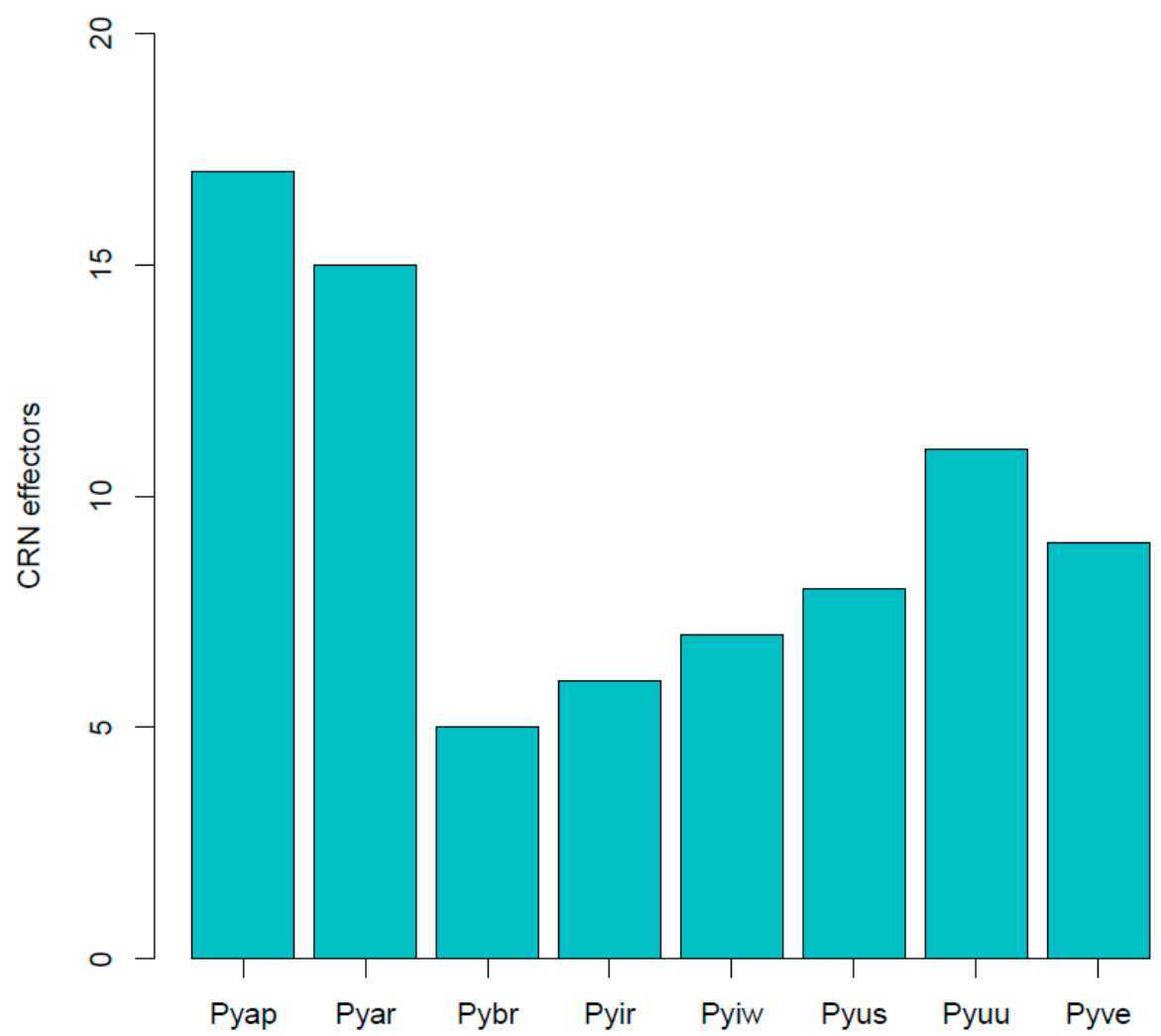

(a)

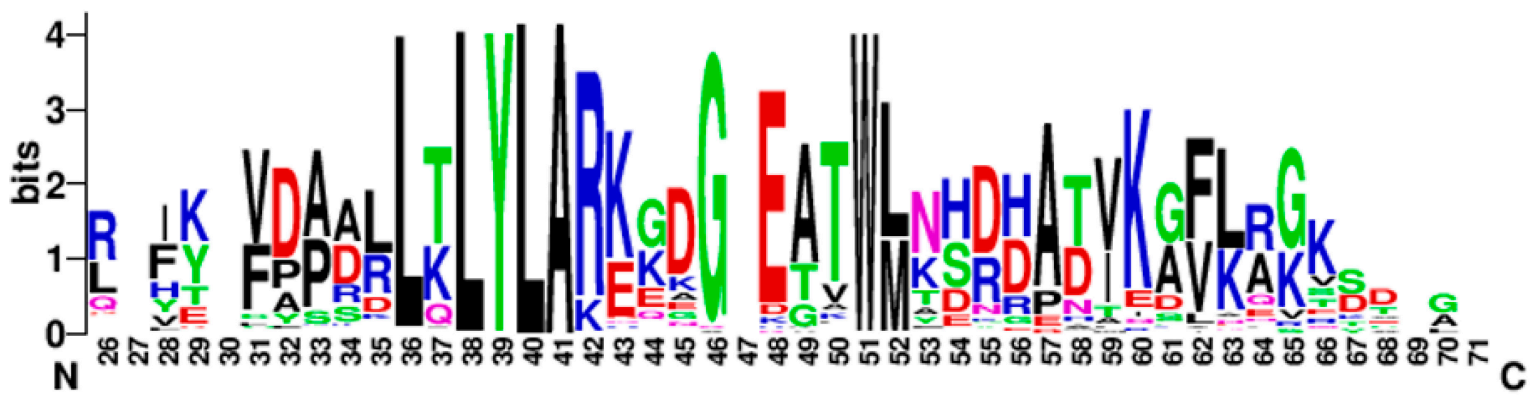

(b)

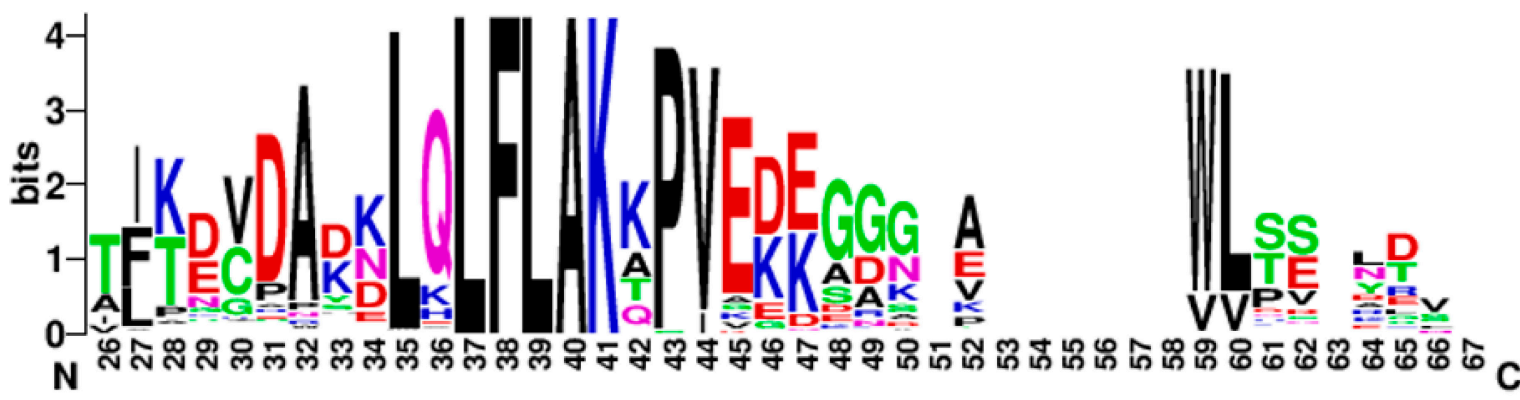

(c)

Figure 5. CRN effectors showing distribution in various Pythium spp. (a), abbreviations as in Figure 4, LYLAR or LYLAK motif (b), and LXLFLAK motif (c). The number of candidate CRN effectors in each genome was estimated as above with YxSL[RK] effectors. 
The general reduction across all the effector classes in P. brassicum P1 is likely a result of the switch to host specialization in this species. As fewer hosts are utilized, a less diverse effector repertoire would be required to invade and colonize those hosts.

\subsection{Carbohydrate Metabolism}

We also annotated the carbohydrate-active enzymes in Pythium and other oomycete genomes using the CAZy database [30]. Carbohydrate-active enzymes aid in breaking down cell walls and other components of plant cells [31]. In general, P. brassicum P1 had an average number of proteins falling in the "Auxiliary Activities" category for Pythium species (P. brassicum P1: 20 genes in category, Pythium average: 20.75), a nearly average number of proteins in the "Carbohydrate Binding Module" category (P1: 50, Pythium average: 51.875), a below average number of carbohydrate esterases (P1: 43, Pythium average: 53.25), a below average number of glycoside hydrolases (P1: 133, Pythium average: 138), a slightly below average number of glycosyl transferases (P1: 104, Pythium average: 107.625), and a below average number of polysaccharide lyases (P1: 12, Pythium average: 16.125).

Among Pythium species, P. brassicum P1 had a reduced number of proteins falling under carbohydrate binding module (CBM) 47, which plays a role in fucose binding; glycoside hydrolase (GH) 12, a xyloglucan hydrolase; $\mathrm{GH} 81$, an endo- $\beta$-1,3-glucanase; carbohydrate esterase (CE) 1, a family that contains acetyl xylan esterases, cinnamoyl esterases, and carboxylesterases, among others; and CE 10, a family that contains acetylcholinesterases, cholinesterases, and sterol esterases. Pythium brassicum P1 showed increased numbers of CE 4, a family that includes chitin deacetylases, chitooligosaccharide deacetylases, and peptidoglycan GlcNAc deacetylases; GH 7, a family that includes reducing end-acting cellobiohydrolases and chitosanases; glycosyl transferase (GT) 48, a 1,3- $\beta$-glucan synthase; and GT 32, which includes $\alpha$-1,6-manosyltransferases and inositol-phosphorylceramide transferases (Figure 6a-d, Table 4).

Table 4. Number of proteins in protein families known to be involved in host plant disease development in P. brassicum P1 and other oomycetes and fungal species.

\begin{tabular}{|c|c|c|c|c|c|c|c|c|c|c|c|c|c|c|c|c|c|}
\hline & Pap $^{a}$ & Par & $\mathrm{Pbr}$ & Pir & Piw & Pus & Puu & Pve & Phi & Phr & Phs & Har & Sap & Fgr & Mor & Uma & Ror \\
\hline $\mathrm{ABC}$ transporters & 171 & 165 & 90 & 205 & 246 & 177 & 247 & 243 & 214 & 253 & 241 & 73 & 223 & 106 & 87 & 70 & 79 \\
\hline Aspartyl proteases & 33 & 36 & 25 & 28 & 24 & 24 & 49 & 20 & 15 & 58 & 65 & 10 & 16 & 26 & 22 & 14 & 150 \\
\hline Cutinases & 9 & 7 & 0 & 0 & 0 & 0 & 0 & 0 & 4 & 4 & 15 & 20 & 0 & 12 & 18 & 4 & 0 \\
\hline Cysteine proteases & 29 & 35 & 37 & 36 & 39 & 32 & 37 & 28 & 33 & 35 & 33 & 22 & 79 & 6 & 7 & 5 & 1 \\
\hline Cytochrome P450s & 31 & 60 & 12 & 53 & 66 & 32 & 39 & 27 & 26 & 29 & 38 & 14 & 44 & 110 & 134 & 22 & 48 \\
\hline Elicitin-like proteins & 37 & 41 & 24 & 45 & 34 & 27 & 43 & 30 & 42 & 77 & 56 & 16 & 23 & 0 & 0 & 0 & 0 \\
\hline Glycoside hydrolases & 117 & 163 & 133 & 133 & 118 & 110 & 168 & 162 & 273 & 271 & 294 & 98 & 198 & 259 & 266 & 125 & $\mathrm{U}^{\mathrm{b}}$ \\
\hline Lipases & 26 & 26 & 22 & 15 & 11 & 10 & 21 & 24 & 31 & 26 & 47 & 11 & 49 & 40 & 30 & 11 & 37 \\
\hline NPP1-like proteins & 4 & 5 & 3 & 4 & 4 & 4 & 7 & 4 & 28 & 58 & 80 & 32 & 0 & 4 & 5 & 0 & 0 \\
\hline Carbohydrate esterases & 68 & 75 & 43 & 56 & 41 & 29 & 63 & 51 & 76 & 92 & 129 & 34 & 73 & 130 & 125 & 61 & $\mathrm{U}$ \\
\hline Polysaccharide lyases & 22 & 7 & 12 & 14 & 7 & 16 & 29 & 22 & 66 & 53 & 76 & 15 & 5 & 21 & 5 & 2 & $\mathrm{U}$ \\
\hline Phospholipases & 20 & 23 & 15 & 16 & 15 & 11 & 18 & 19 & 31 & 28 & 31 & 16 & 18 & 41 & 26 & 14 & 17 \\
\hline Protease inhibitors & 27 & 23 & 21 & 28 & 19 & 22 & 31 & 14 & 60 & 25 & 59 & 2 & 14 & 0 & 0 & 0 & 0 \\
\hline RxLR effectors & 0 & 0 & 0 & 0 & 0 & 0 & 0 & 0 & 563 & 350 & 350 & 7 & 0 & 0 & 0 & 0 & 0 \\
\hline
\end{tabular}

a Pap, Pythium aphanidermatum; Par, Pythium arrhenomanes; Pbr, Pythium brassicum; Pir, Pythium irregulare; Piw, Pythium iwayamai; Pus, Pythium ultimum var. sporangiiferum; Puu, Pythium ultimum var. ultimum; Pve, Pythium vexans; Phi, Pythophthora infestans; Phr, Phytophthora ramorum; Phs, Phytophthora sojae; Har, Hyaloperonospora arabidopsidis; Sap, Saprolegnia parasitica; Fgr, Fusarium graminearum; Mor, Magnaporthe oryzae; Uma, Ustilago maydis; Ror, Rhizopus oryzae. ${ }^{b}$ Undetermined.

The total number of candidate glycoside hydrolases (GHs) identified in P. brassicum P1 was 133. This is compared to 180 candidate GHs reported in P. ultimum [19]. Similar to P. ultimum [19], P. brassicum P1 did not possess any candidate cutinases in its genome, suggesting that, like P. ultimum, P. brassicum P1 infects host plants through non-suberized young roots as well as wounds. We did not identify any xylan degrading enzymes in the genome of P. brassicum P1, consistent with previous reports in P. ultimum and other Pythium spp. ([19] and references therein). 
CAZyme Counts

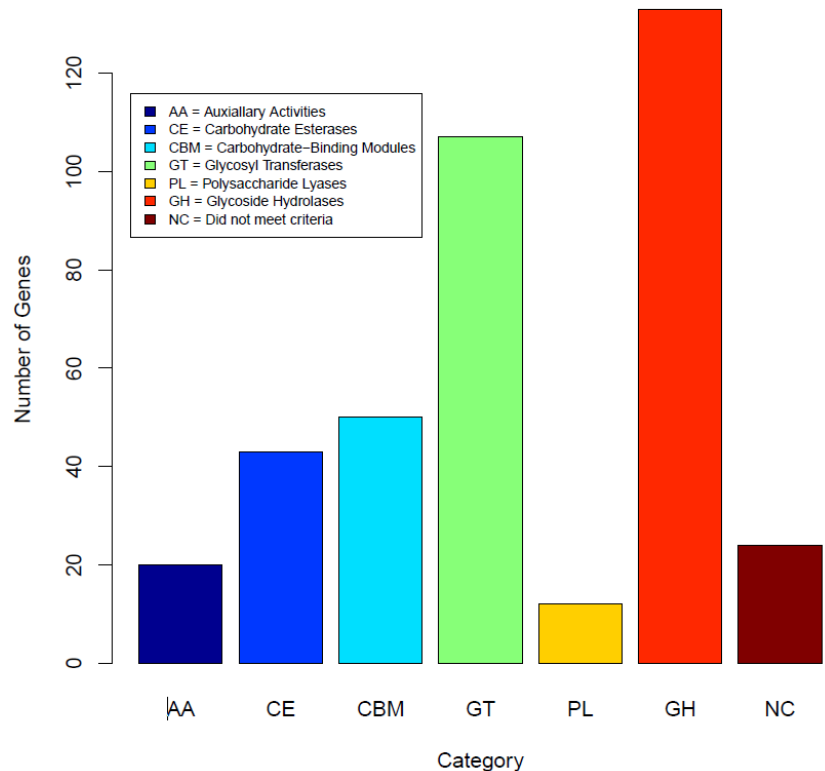

(a)

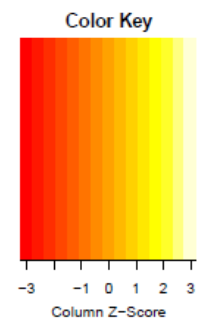

Auxillary Activities

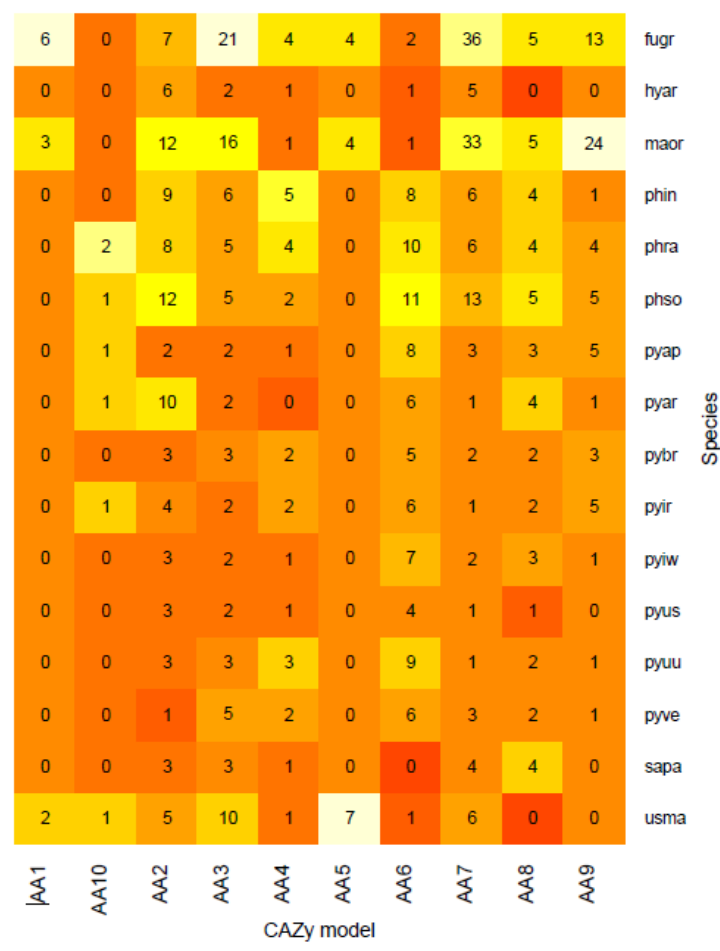

(b)

Figure 6. Cont. 


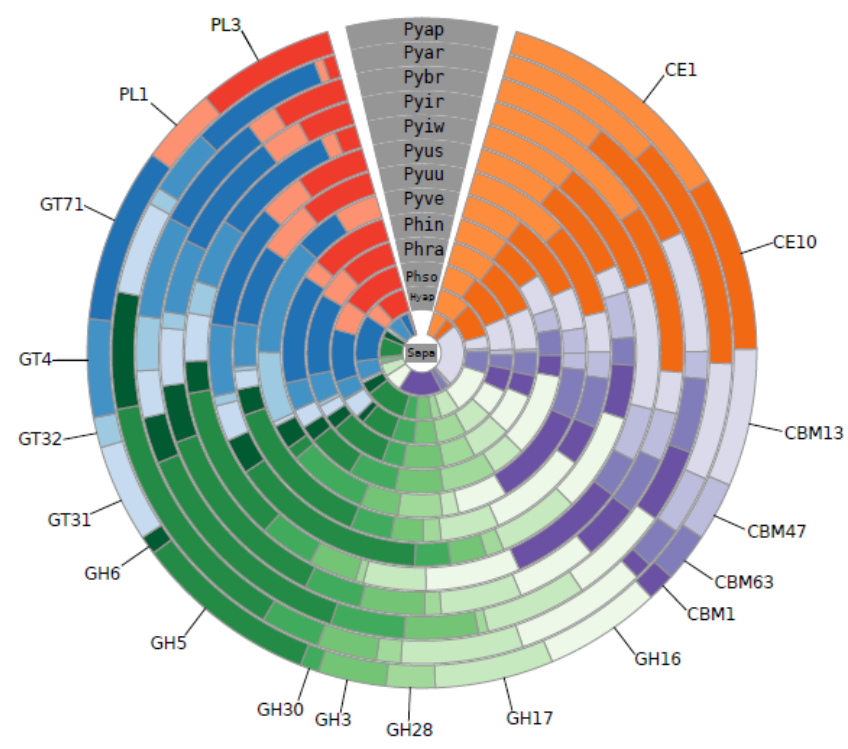

(c)

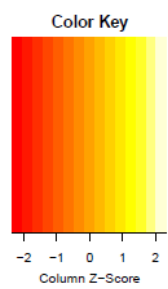

Auxillary Activities

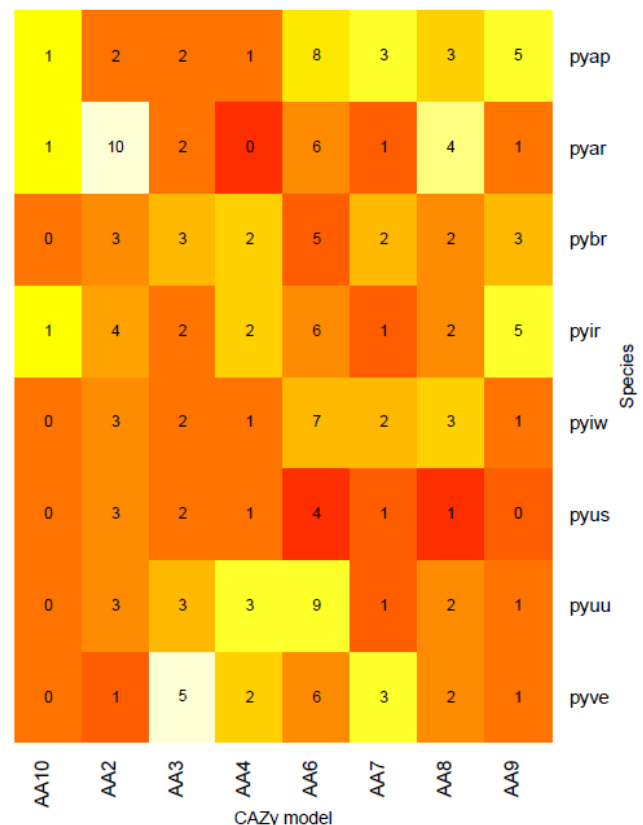

(d)

Figure 6. Carbohydrate-active enzymes (CAZymes) plots of each class (a), heatmaps (b), circos (c), and Pythium specific CAZy analysis (d). Annotation of the CAZyme-coding genes was done using the CAZymes Analysis Toolkit-CAT based on the CAZy database in combination with protein family domain analysis.

Pectin degrading enzymes or pectinases are known to play a key role in host plant infection by Pythium spp. Pythium ultimum is reported to have 29 candidate pectinase/pectin lyases [19] as compared to P. brassicum P1, which had only 12 predicted pectinase/pectin lyase. In addition to pectinases, $P$. ultimum has $\alpha$-amylase, glucoamylase, and invertase 
genes that target starch and sucrose in the host plant [19]; three candidate starch and sucrose degrading enzymes were detected in the P. brassicum P1 genome. Again, the reduction in genes known to play a role in plant invasion in P. brassicum P1 is likely a result of the transition to host specificity.

\subsection{Phylogenetic Position}

We used OrthoMCL [25] to identify single-copy orthologs across all published Pythium genomes, as well as several other oomycete and fungal genomes. We then aligned these single-copy orthologs and constructed a phylogenetic tree using RAxML [32] (Figure 7). Pythium brassicum P1 shared the most recent common ancestor with P. iwayamai and P. irregulare; that divergence was one of the more recent ones within Pythium, though there are three species pairs with more recent divergences. The next most recent common ancestor of brassicum/iwayamai/irregulare is shared with the two variants of P. ultimum. Together, these five species represent the only monophyletic Pythium clade in our tree. All other clades that included Pythium also included other oomycete species.

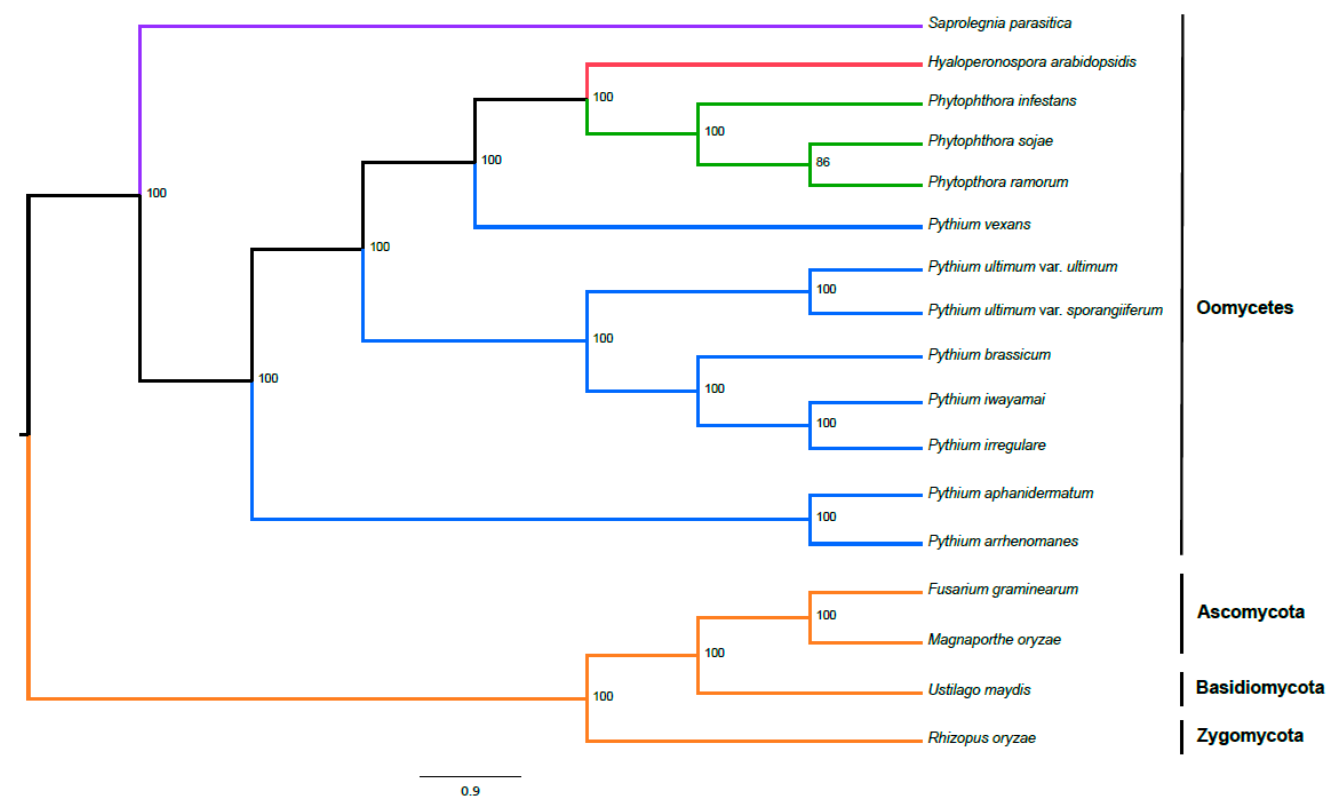

Figure 7. Phylogeny of P. brassicum P1 and other select oomycetes including Saprolegnia, Hyaloperonospora, Phytophthora and Pythium based on genome sequencing as inferred by maximum likelihood analysis. Outgroups include Fusarium graminearum and Magnaporthe grisea (Ascomycetes), Ustilago maydis (Basidiomycetes) and Rhizopus oryzae (Zygomycetes). Numbers on each node represent the percentage of bootstraps that support that node. Colors of the branches correspond to different genera (in the case of oomycetes) or outgroup fungi (orange: fungi; blue: Pythium; green: Phytophthora; red: Hyaloperonospora; and purple: Saprolegnia).

\subsection{Shared Gene Clusters of Oomycetes}

We further performed a comparison of important pathogenicity protein families among all oomycetes (Table 3). Pythium brassicum P1 showed a reduction in ABC transporters, aspartyl proteases, cytochrome p450s, and elicitin-like proteins. There were no important pathogenicity protein families in which P. brassicum P1 showed a large expansion. In general, Pythium species show reduced numbers of glycoside hydrolases, NPP1-like proteins, carbohydrate esterases, polysaccharide lyases, and protease inhibitors relative to Phytophthora species, and show no evidence of RxLR effectors. Again, there appears to be no important pathogenic proteins that show expansions in Pythium species relative to Phytophthora species. 


\subsection{Orthologous Gene Clusters of Oomycete and Fungal Taxa}

Similar to our analysis of a Pythium core genome and species-specific clusters of orthologous genes above, we performed an analysis grouping our 8 Pythium genomes, 3 Phytophthora genomes, 2 other oomycete genomes, and 4 fungal genomes (Figure 8). In this analysis, Pythium species had 3631 unique clusters containing 11,620 genes; Phytophthora species had 3042 unique clusters containing 11,134 genes; the other oomycete species had 1732 unique clusters containing 6833 genes; and fungi had 6067 unique clusters containing 19,755 genes. There are 210 clusters and 1158 genes shared among all four classes analyzed.

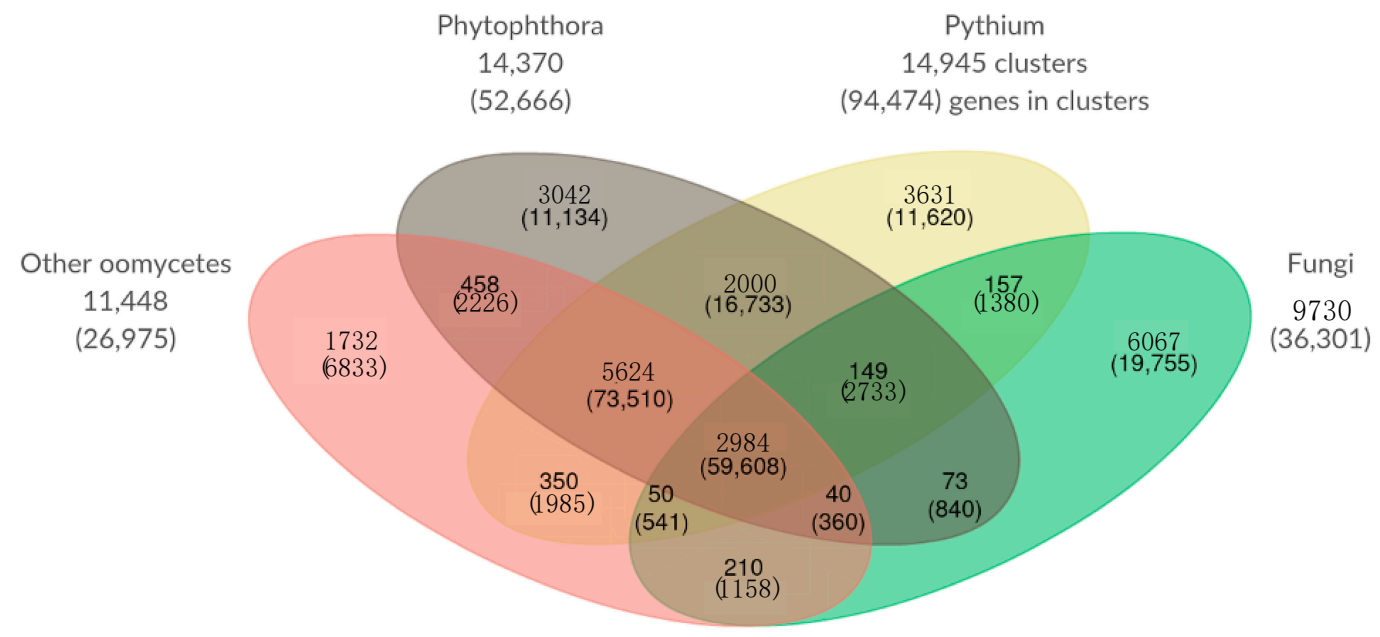

Figure 8. Comparison of orthologous gene clusters of Pythium species, Phytophthora species, Fungi, and other oomycetes. The number of gene clusters and total number of genes contained within those clusters (in parentheses) is displayed for each overlapping category. The numbers outside the Venn diagram show the total number of gene clusters (and genes) in each set.

\subsection{Synteny with Other Oomycete Plant Pathogens}

A comprehensive analysis of synteny was carried out with all oomycete species using MCscan [33] (see Figure 9a-e). In general, we observed no evidence of large-scale inversions or rearrangements. We did, however, see some evidence of translocations in Hyaloperonospora arabidopsidis and Pythium aphanidermatum, relative to P. brassicum P1. Given that none of these genomes are resolved to chromosome level, these results must be met with caution.

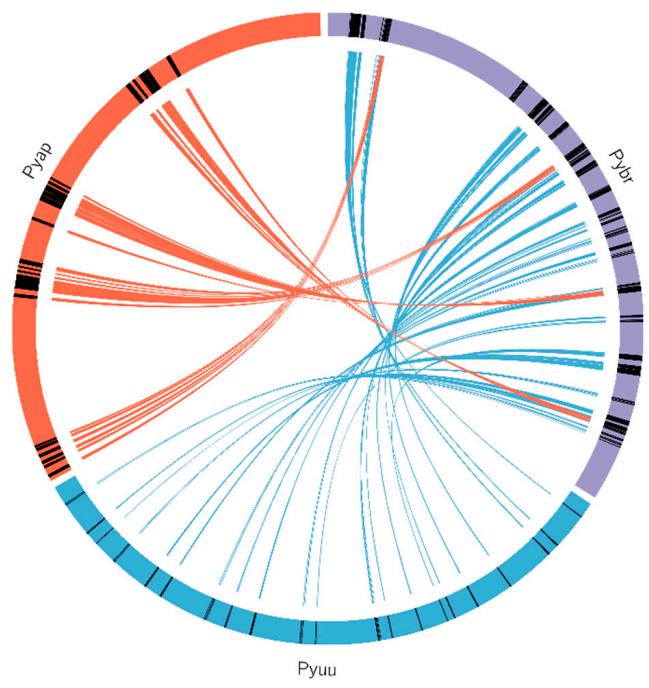

(a)

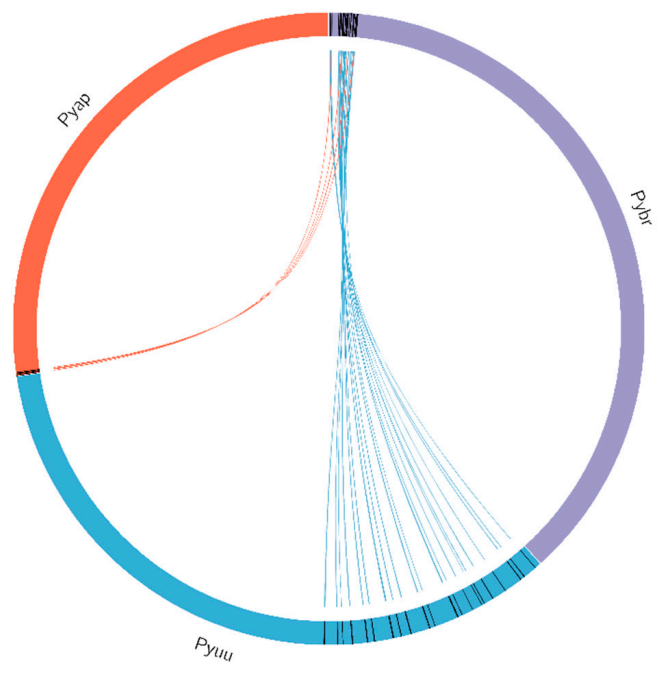

(b)

Figure 9. Cont. 


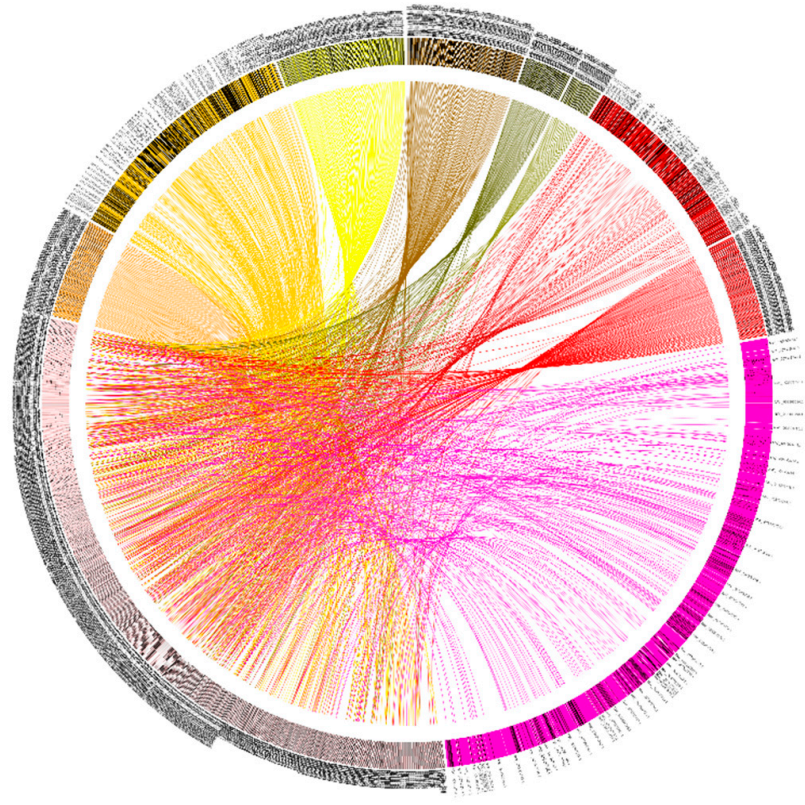

(c)

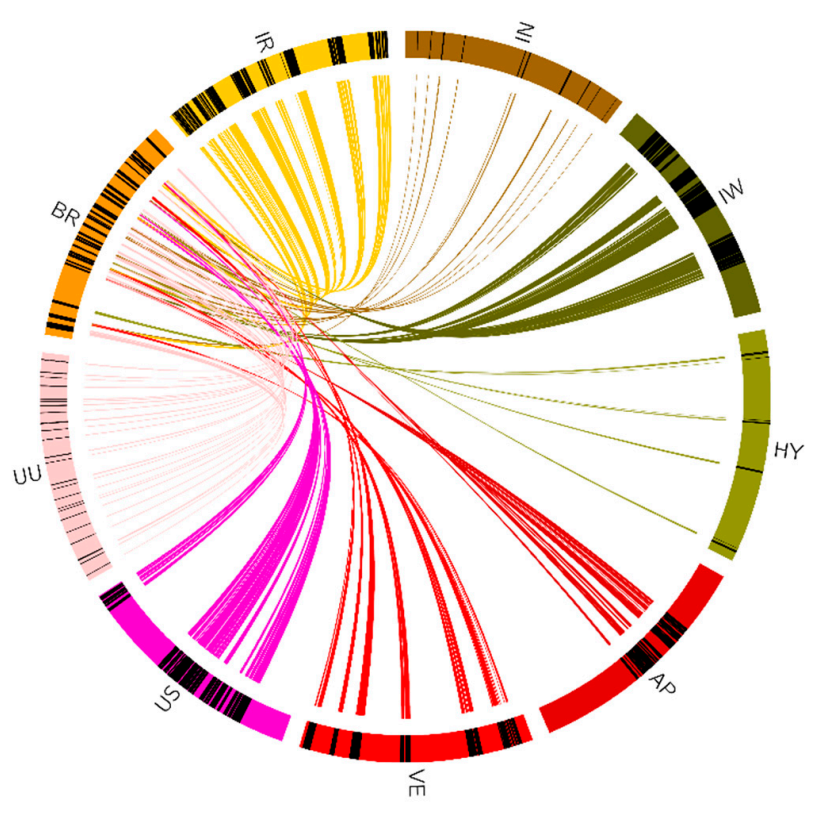

(d)

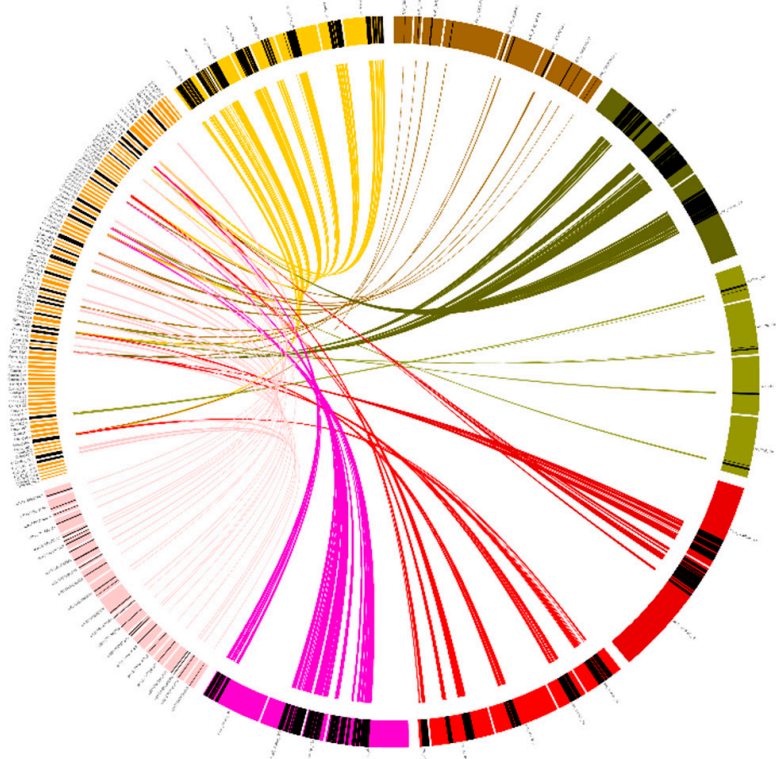

(e)

Figure 9. Synteny between the Pythium brassicum genome and several other oomycete genomes. Syntenic regions (as determined by MCScan) between P. brassicum and several other oomycete genomes is depicted. Lines connecting genomes indicate syntenic regions. (a) Synteny between select regions of P. brassicum (Pybr, purple), P. ultimum var. ultimum (Pyuu, blue), and P. aphanidermatum (Pyap, red). (b) Synteny across whole genomes of the species depicted in (a). (c) Synteny across selected genome regions for several oomycete species, scaled to the size of each genome (clockwise from top: Ph. infestans, P. iwayamai, H. arabidopsidis, P. aphanidermatum, P. vexans, P. ultimum var. sporangiiferum, P. ultimum var. ultimum, P. brassicum, P. irregulare, and Ph. Ramorum). (d) Synteny across select genome regions of several oomycete species, scaled so each genome is the same physical size on the graph (IN: Ph. Infestans, IW: P. iwayamai, HY: H. arabidopsidis, AP: P. aphanidermatum, VE: P. vexans, US: P. ultimum var. sporangiiferum, UU: P. ultimum var. ultimum, BR: P. brassicum, and IR: P. irregulare). (e) Same as (d) but scaled to the size of each genome. 


\section{Conclusions}

Pythium brassicum P1 is an oomycete with a narrow host range infecting mustard family (Brassicaceae) only. This is in contrast to the majority of Pythium species, including P. ultimum, that have a wide host range infecting hundreds of diverse plant species. This study was thus designed to identify diverse biological parameters or mechanisms which might be responsible for P1's narrow host range and where it could fit within a broader phylogenetic profile. We identified and sequenced the whole genome of a new P. brassicum P1 strain and compared to those with broad host range. Only a few species possess a narrow host range, and these include P. iwayamai and P. arrhenomanes which are pathogenic to monocotyledonous grasses. Both P. ultimum and P. brassicum P1 lack the hallmark RxLR effectors. One of the reasons for the absence of RxLR effectors in Pythium species is thought to be due to necrotrophic infection they cause on seedlings and stressed plants with weak defenses in contrast to other oomycete pathogens that possess RxLR effectors and are considered biotrophic, acquiring their nutrients from living cells. Most recently, Ai et al. [34] have reported the existence of functional RxLR effectors that induce tissue necrosis in several Pythium spp. including P. utimum. They argued that the existing genome annotation models seem to be inadequate for $R x L R$ gene prediction and as a result they developed a modified regex model to allow the search for degenerate dEER motifs. Pythium brassicum P1 had three Crinkler (CRN) class of effectors with LYLA(R/K) motif compared to P. ultimum with 18 predicted CRN proteins [19], whereas Phytophthora spp. possess a large number of Crinklers that enter the host cells and trigger cell death and necrotrophy [23]. Like P. ultimum [19], P. brassicum P1 genome contained secreted proteins with a conserved RxLRlike motif (YxSL[KR]) that may act inside host cells during infection. Similar to P. ultimum, P. brassicum $\mathrm{P} 1$ lacked any cutinases suggesting that it may infect young seedlings through un-suberized root tissue as well as tissue wounds. This is in contrast to P. arrhenomanes and P. aphenodermatum that possess a total of 6 and 8 cutinase-encoding genes, respectively. The P. brassicum P1 genome encoded a much smaller number of cellulase and pectinase genes than P. ultimum. These genes facilitate initial penetration and infection of the host, and the narrower host range of $P$. brassicum $\mathrm{P} 1$ relative to $P$. ultimum may explain the reduction in the number of genes involved in host plant invasion. In vitro growth studies have shown that $P$. ultimum was unable to utilize complex polysaccharides such as xylan and chitin, but it easily degraded starch and sucrose $[19,35]$. Given that $P$. brassicum P1 similarly lacked xylanases, but had a limited set of pectinases, it would be expected that P. brassicum P1 possesses similar abilities to degrade starch and sucrose, though the range of these sugar molecules utilized by P. brassicum P1 may be limited. The inability of $P$. brassicum P1 to invade and colonize non-Brassicaceae species could be attributed, among other factors, to the lack of a wide repertoire of functional genes encoding cell wall degrading enzymes in its genome.

\section{Key Points}

We identified and sequenced a new pathogen genome (named as Pythium brassicum P1) that infects only the Brassicaceae family of plants.

(i). Comprehensive bioinformatics analysis (e.g., comparison to 13 oomycete and 4 fungal outgroup species) revealed contracted regulation of metabolism, protein families, and distinct pathogenicity repertoire.

(ii). Assembled genome size is $50.3 \mathrm{Mb}$ contained in 5434 scaffolds and 13,232 putative protein-coding genes identified; a detailed annotation analysis was performed.

(iii). Identified 175 species-specific gene families in P. brassicum, slightly below the normal average of other oomycetes, and a possible reason for the narrow host range of P. brassicum.

(iv). In contrast to other fungal or oomycetes, $P$. brassicum genome did not encode any classical RxLR effectors or cutinases, suggesting a significant difference in virulence mechanisms.

(v). A wide comparative analysis (e.g., over- and under-represented gene families, core specific gene families, secretome, $\mathrm{Ca}^{2+-}$ dependent adherens, effector repertoire, 
carbohydrate metabolism analysis, phylogenetic position, identification of shared and orthologous gene clusters, and synteny analysis with other plant pathogens) led to the identification of diverse biological parameters or mechanisms responsible for P1's narrow host range.

\section{Materials and Methods}

\subsection{DNA Extraction and Purification}

Pythium brassicum isolate P1 was grown in $25 \mathrm{~mL} \mathrm{10 \%}(v / v)$ V8 juice broth, supplemented with $300 \mu \mathrm{g} / \mathrm{mL}$ vancomycin (to inhibit bacterial growth) at room temperature on a rotary shaker set at $150 \mathrm{rpm}$ for seven days. V8 juice broth was inoculated with five agar plugs cut from the advancing mycelium of a three-day old V8 agar culture plate. The mycelia were vacuum-filtered on a Whatman filter paper placed on a Buchner funnel, washed a few times in sterile distilled water, blot-dried, and pulverized in frozen mortar and pestle using liquid nitrogen.

Genomic DNA was extracted using the protocol for yeast GenJET genomic DNA purification Kit (Thermo Fisher Scientific, Carlsbad, CA, USA). Briefly, $180 \mu \mathrm{L}$ of digestion solution mixed with $20 \mu \mathrm{L}$ protease $\mathrm{K}$ was added to the powdered mycelium in sterile centrifuge tube, mixed by vortexing and incubated at $56{ }^{\circ} \mathrm{C}$ for 45 min with occasional inversion. This was followed by adding $20 \mu \mathrm{L}$ RNase A solution, mixing, and incubating at room temperature for $10 \mathrm{~min}$. Two hundred $\mu \mathrm{L}$ lysis solution was added to the mixture, and the mixture was vortexed for $15 \mathrm{~s}$. After adding $400 \mu \mathrm{L}$ of $50 \%$ ethanol, the lysate was mixed and transferred onto GenJet column. The tube was centrifuged for at $8000 \times g$ for $1 \mathrm{~min}$, flow through was discarded, column was placed on a new collection tube, $500 \mu \mathrm{L}$ wash buffer I was added, tube was centrifuged for as above, flow through was discarded, column was washed with buffer II and centrifuged at $12,000 \times g$ for $3 \mathrm{~min}$. Finally, $200 \mu \mathrm{L}$ elution buffer was added to the column, incubated at room temperature for $2 \mathrm{~min}$, and centrifuged for $1 \mathrm{~min}$ at $8000 \times \mathrm{g}$. Eluent containing DNA was run on agarose gel to examine for DNA integrity. DNA concentration and quality were measured using Nanodrop ND-1000 spectrophotometer.

\subsection{DNA Library Preparation and Sequencing}

Quality of genomic DNA template was analyzed by Agilent 2100 Bioanalyzer for Illumina sample preparation. For Next-Generation Sequencing, a total of 358 ng DNA in $130 \mu \mathrm{L}$ was sheared using Covaris Focused-ultrasonicator ${ }^{\mathrm{TM}}$ Model S220 generating fragments with an average size of $436 \mathrm{bp}$. The NEBNext Ultra DNA Library Prep Kit for Illumina was used following the protocol provided with index\#8 (New England BioLabs Inc., Ipswich, MA, USA).

The whole genome sequencing of P. brassicum P1 (CBS137315; MycoBank810861) was performed using Illumina HiSeq 2500. The run specifications were $2 \times 101 \times 7$ cycles, version 3 flowcell, HCS 2.0.12.0, and RTA 1.17.21.3. The library was loaded at $10.0 \mathrm{pM}$ across the flowcell which resulted in a cluster density of $747 \mathrm{k} / \mathrm{mm}^{2}$, a $91 \%$ Pass Filter rate, and 374 million total reads Passing Filter. The sequence Read 1 quality was $91.4 \%$ of bases $\geq$ Q30, and the sequence Read 2 quality was $86.9 \%$ of bases $\geq$ Q30.

\subsection{Genome Assembly and Gene Prediction}

Genome sequencing of the P. brassicum P1 was performed on a single library in a single lane of the Illumina HiSeq 2500 with $101 \mathrm{bp}$, paired-end reads. Barcode and adapter sequences were trimmed using the FASTX Toolkit (available online: http:// hannonlab.cshl.edu/fastx_toolkit/index.html) (accessed on 26 February 2021), reads were filtered, and quality control was performed. Assembly was carried out on both the raw and filtered reads using Velvet [36], the String Graph Assembler (SGA) [37], and SOAPdenovo2 [17]. Velvet and SOAPdenovo2 assemblies were carried out with $k$-mers of $35-99$, with a step size of four. SGA does not use a $k$-mer assembly, and the assembly was carried out with default parameters. Upon completion of assembly, the best 
assembly was selected (based on largest N50 and longest maximum scaffold length, and number of scaffolds) and used for further analysis. This assembly was then reassembled with CAP3 program [18] using default parameters. The CAP3 reassembly program was repeat masked using RepeatScout software [22]. Gene prediction was carried out on the repeat masked assembly using the MAKER pipeline [20]. Seven previously published Pythium proteomes (downloaded from the Pythium Genome Database (http: / / pythium.plantbiology.msu.edu/, no longer available online)) were provided as evidence to the SNAP for gene model building and P. ultimum ESTs were provided to the MAKER to further refine the predictions. BUSCO (Benchmarking Universal Single-Copy Orthologs) was used to assess genome completeness [21]. The whole genome Shotgun project has been deposited in the NCBI/GenBank under the accession\# ASM827159v1 (available online: https:/ / www.ncbi.nlm.nih.gov/assembly/GCA_008271595.1/) (accessed on 15 August 2021).

\subsection{Identification of Orthologous Groups}

OrthoMCL [25] was used to identify clusters of orthologous genes among all of the genomes used in subsequent analyses. OrthoMCL started with an all-vs-all BLAST of all genes used in the analysis. These results were then filtered to remove hits of proteins to themselves, after which the Markov Cluster Algorithm, as implemented in MCL [38], was used to cluster proteins by similarity and orthologous clusters were constructed. The output from OrthoMCL was then used in a number of downstream analyses, outlined below.

\subsection{Phylogenetic Analyses}

A phylogeny of 13 oomycete species (8 Pythium, 3 Phytophthora, Hyaloperonospora arabidopsidis, and Saprolegnia parasitica) and four fungal outgroup species (Magnaporthe oryzae, Fusarium graminearum, Rhizopus oryzae, and Ustilago maydis) was constructed with RAxML [31]. Multiple sequence alignments of 341 single copy orthologs present in every genome, as determined by OrthoMCL [25], were aligned using MAFFT [39] and then passed to RAxML, which was run using the GAMMA model of rate heterogeneity and the LG model of substitution. One thousand bootstrap simulations were run, and the final tree was visualized using FigTree (available online: http://tree.bio.ed.ac.uk/software/figtree/) (accessed on 15 March 2021).

\subsection{Analysis of P. brassicum P1 Over-and Under-Represented Families}

Two methods were employed to determine the gene families that were significantly over- or under-represented in the P. brassicum P1 genome. The first was implemented in CAFE [40], which used a stochastic birth-death model to determine gene families that were significantly expanding or contracting (relative to ancestral state) along each branch of a phylogeny. Input for CAFE included the phylogenetic tree constructed with RAxML and the clusters of orthologous genes from OrthoMCL. After determining which gene families were significantly expanding or contracting on the branch leading to P. brassicum P1, a representative member from that family was selected and annotated with Pfam [41]. The second method used to determine over- and under-represented gene families in P. brassicum P1 was a one-to-one comparison of PANTHER protein family annotations [42] in the genomes of P. brassicum P1, and a generalist species of Pythium, P. ultimum var. ultimum. First, the set of PANTHER HMMs was downloaded from: http:/ / data.pantherdb. org/ftp/panther_library/current_release/ (available online, accessed on 17 March 2021). Each of the two genomes in the analysis was then annotated for PANTHER protein family content using the script pantherScore2.2.pl, available here: http://data.pantherdb.org/ $\mathrm{ftp} / \mathrm{hmm} \_$scoring/current_release/pantherScore2.2/ (available online, accessed on 17 March 2021). After scoring each genome against the set of PANTHER HMMs, hits were filtered to include only those considered to be a close match, per the criteria laid out in the PANTHER manual. A list of P. brassicum P1 genes and their PANTHER annotations and P. ultimum var. ultimum genes and their PANTHER annotations were then uploaded to 
http:/ / pantherdb.org/tools/ compareToRefList.jsp (available online, accessed on: 15 March 2021), which used a Fisher's exact test with false discovery rate correction to determine PANTHER families that were over-represented in one genome relative to another.

\subsection{Identification of Putatively Secreted Proteins}

The P. brassicum P1 predicted proteome was analyzed using the default parameters of SignalP [26] to identify proteins with secretion signals. Transmembrane domains were also predicted using TMHMM [43]. Proteins with: (i) no predicted transmembrane domains, (ii) SignalP Ymax score $\geq 0.5$, (iii) SignalP D score $\geq 0.5$, (iv) SignalP Smax score $\geq 0.9$, and (v) SignalP secreted prediction equal to "Y" were considered as the secreted proteins of P1.

\subsection{Analyses of Carbohydrate-Active Enzymes}

All the genomes were further annotated for carbohydrate-active enzyme (CAZy) content [20] using the CAZymes Analysis Toolkit [44]. This method used two approaches to annotate the genome for CAZyme content: (1) a sequence similarity search against the entire CAZy database, and (2) an analysis of links between proteins and CAZymes using protein family domains.

\subsection{Identification of Candidate Effectors}

The known effector sequences for the effector classes that we looked at (YxSL, CRN, and RxLR) were downloaded from GenBank and aligned using MAFFT [39]. These alignments were used to create Hidden Markov Models for each effector class using HMMER (hmmer.org, version 3.1b2), after which the hmmscan algorithm in HMMER was used to search all protein sequences for all genomes used in our analyses against the profile HMMs created. Proteins that were identified as secreted as described above and that positively matched the profile HMMs were regarded as effectors falling into the respective class of the positive profile HMM. Further, string searches using Perl regular expressions were carried out to determine whether any potential effectors were missed using the methods above.

\subsection{Synteny Analysis}

All protein coding genes from all the 8 Pythium species used in the analyses in this paper were subjected to an all-vs-all BLASTP [45]. These results were used as the input for MCscan [33]. A python script contained in the MCscan package was used to filter the initial BLASTP results, remove self-hits, and order gene pairs for downstream analysis. Filtered BLASTP results were then clustered using the Markov Cluster Algorithm implemented in MCL [38]. The output of MCL, as well as the filtered/re-order BLASTP results and genomic BED files, were then supplied to MCscan to calculate pairwise synteny between P. brassicum $\mathrm{P} 1$ and all other Pythium genomes used in the analysis. The '- $\mathrm{b}$ ' option was used to limit within-genome synteny, all other parameters were left at program defaults. Custom Perl scripts were used to parse the MCscan output and generate input files for Circos [46], which was used to visualize the synteny among the genomes.

Supplementary Materials: The following are available online at https:/ /www.mdpi.com/article/10 $.3390 /$ ijms22169002/s1.

Author Contributions: Conceptualization, M.M. and M.E.S.; methodology, M.M., E.A.S., R.K.; data analysis and validation: E.A.S. and R.K.; writing and editing: M.M., E.A.S., M.E.S. and R.K.; M.M. and E.A.S. contributed equally. All authors have read and agreed to the published version of the manuscript.

Funding: This research was partially supported by the Utah Agricultural Experiment Station (UAES), Utah State University, and approved as journal paper number 9513. The funding body did not play any role in the design of this study; the collection, analysis, or interpretation of data; or in the writing of this manuscript.

Institutional Review Board Statement: Not applicable. 
Informed Consent Statement: Not applicable.

Data Availability Statement: The whole genome shotgun project data have been deposited in the NCBI/GenBank and are available as accession \# ASM827159v1 (available online: https:/ / www.ncbi. nlm.nih.gov/assembly/GCA_008271595.1/) (accessed on 15 August 2021).

Acknowledgments: We thank Holly Eckelhoefer and John Weger at the Genomics Core, Institute for Integrative Genome Biology, University of California, Riverside, for DNA bioanalysis, preparing P1 genomic libraries and performing Illumina sequencing. The authors also thank the anonymous referees for help in improving the research article.

Conflicts of Interest: The authors declare no conflict of interest.

\section{References}

1. Beakes, G.W.; Glockling, S.L.; Sekimoto, S. The Evolutionary Phylogeny of the Oomycete "fungi". Protoplasma $2012,249,3-19$. [CrossRef] [PubMed]

2. Ho, H.H. The Taxonomy and Biology of Phytophthora and Pythium. J. Bacteriol. Mycol. Open Access 2018, 6, 40-45. [CrossRef]

3. Lévesque, C.A.; de Cock, A.W.A.M. Molecular Phylogeny and Taxonomy of the Genus Pythium. Mycol. Res. 2004, 108, 1363-1383. [CrossRef] [PubMed]

4. van der Plaats-Niterink, A.J. Monograph of the Genus Pythium. Stud. Mycol. 1981, 21, 1-242. Available online: https://www.cabi. org/isc/abstract/19821379677 (accessed on 16 August 2020).

5. Martin, F.N.; Loper, J.E. Soilborne Plant Diseases Caused by Pythium spp: Ecology, Epidemiology, and Prospects for Biological Control. Crit. Rev. Plant Sci. 1999, 18, 111-181. [CrossRef]

6. Gold, S.E.; Stanghellini, M.E. Effects of Temperature on Pythium Rot of Spinach Spinacia oleracea Grown under Hydroponic Conditions. Phytopathology 1985, 75, 333-337. [CrossRef]

7. Martin, F.N. Pythium Genetics. In Oomycete Genetics and Genomics: Diversity, Interactions and Research Tools; Lamour, K., Kamoun, S., Eds.; John Wiley \& Sons: Hoboken, NJ, USA, 2009; p. 574.

8. Bridge, P.D.; Newsham, K.K.; Denton, G.J. Snow Mould Caused by Pythium sp.: A Potential Vascular Plant Pathogen in the Maritime Antarctic. Plant Pathol. 2008, 57, 1066-1072. [CrossRef]

9. de Cock, A.W.A.M.; Lodhi, A.M.; Rintoul, T.L.; Bala, K.; Robideau, G.P.; Abad, Z.G.; Coffey, M.D.; Shahzad, S.; Lévesque, C.A. Phytopythium: Molecular Phylogeny and Systematics. Persoonia Mol. Phylo. Evol. Fungi 2015, 34, 25-39. [CrossRef]

10. Vawdrey, L.L.; Langdon, P.; Martin, T. Incidence and Pathogenicity of Phytophthora palmivora and Pythium vexans Associated with Durian Decline in far Northern Queensland. Australas Plant Pathol. 2005, 34, 127-128. [CrossRef]

11. Zeng, H.C.; Ho, H.H.; Zheng, F.C. Pythium vexans Causing Patch Canker of Rubber Trees on Hainan Island, China. Mycopathologia 2005, 159, 601-606. [CrossRef] [PubMed]

12. Adhikari, B.N.; Hamilton, J.P.; Zerillo, M.M.; Tisserat, N.; Lévesque, C.A.; Buell, C.R. Comparative Genomics Reveals Insight into Virulence Strategies of Plant Pathogenic Oomycetes. PLoS ONE 2013, 8, e75072. [CrossRef]

13. Ascunce, M.S.; Huguet-Tapia, J.C.; Braun, E.L.; Ortiz-Urquiza, A.; Keyhani, N.O.; Goss, E.M. Whole Genome Sequence of the Emerging Oomycete Pathogen Pythium insidiosum Strain CDC-B5653 Isolated from an Infected Human in the USA. Genom. Data 2016, 7, 60-61. Available online: https://core.ac.uk/download/pdf/82260744.pdf (accessed on 16 August 2020). [CrossRef] [PubMed]

14. Rujirawat, T.; Patumcharoenpol, P.; Lohnoo, T.; Yingyong, W.; Kumsang, Y.; Payattikul, P.; Tangphatsornruang, S.; Suriyaphol, P.; Reamtong, O.; Garg, G.; et al. Probing the Phylogenomics and Putative Pathogenicity Genes of Pythium insidiosum by Oomycete Genome Analyses. Sci. Rep. 2018, 8, 4135. [CrossRef]

15. McGowan, J.; Fitzpatrick, D.A. Recent Advances in Oomycete Genomics. Adv. Genet. 2020, 105, 175-228. [CrossRef] [PubMed]

16. Stanghellini, M.E.; Mohammadi, M.; Förster, H.; Adaskaveg, J.E. Pythium brassicum sp. nov.: A Novel Plant Family-Specific Root Pathogen. Plant Dis. 2014, 98, 1619-1625. [CrossRef]

17. Luo, R.; Liu, B.; Xie, Y.; Li, Z.; Huang, W.; Yuan, J.; He, G.; Chen, Y.; Pan, Q.; Liu, Y.; et al. SOAPdenovo2: An Empirically Improved Memory-Efficient Short Read De Novo Assembler. Gigascience 2012, 1, 1-6. [CrossRef]

18. Huang, X.; Madan, A. CAP3: A DNA Sequence Assembly Program. Genome Res. 1999, 9, 868-877. Available online: https: / /genome.cshlp.org/content/9/9/868 (accessed on 16 August 2020). [CrossRef] [PubMed]

19. Lévesque, C.A.; Brouwer, H.; Cano, L.; Hamilton, J.P.; Holt, C.; Huitema, E.; Raffaele, S.; Robideau, G.P.; Thines, M.; Win, J.; et al. Genome Sequence of the Necrotrophic Plant Pathogen Pythium ultimum Reveals Original Pathogenicity Mechanisms and Effector Repertoire. Genome Biol. 2010, 11, R73. [CrossRef]

20. Cantarel, B.L.; Korf, I.; Robb, S.M.C.; Parra, G.; Ross, E.; Moore, B.; Holt, C.; Alvarado, A.S.; Yandell, M. MAKER: An easy-to-use Annotation Pipeline Designed for Emerging Model Organism Genomes. Genome Res. 2008, 18, 188-196. [CrossRef]

21. Simão, F.A.; Waterhouse, R.M.; Ioannidis, P.; Kriventseva, E.V.; Zdobnov, E.M. BUSCO: Assessing Genome Assembly and Annotation Completeness with Single-Copy Orthologs. Bioinformatics 2015, 31, 3210-3212. [CrossRef]

22. Price, A.L.; Jones, N.C.; Pevzner, P.A. De novo Identification of Repeat Families in Large Genomes. Bioinformatics 2005, 21, i351-i358. [CrossRef] [PubMed] 
23. Haas, B.J.; Kamoun, S.; Zody, M.; Jiang, R.H.Y.; Handsaker, R.E.; Cano, L.M.; Grabherr, M.; Kodira, C.D.; Raffaele, S.; Torto-Alalibo, T.; et al. Genome Sequence and Analysis of the Irish Potato Famine Pathogen Phytophthora infestans. Nature 2009, 461, 393-398. [CrossRef] [PubMed]

24. Conesa, A.; Götz, S.; García-Gómez, J.M.; Terol, J.; Talón, M.; Robels, M. Blast2GO: A Universal Tool for Annotation, Visualization and Analysis in Functional Genomics Research. Bioinformatics 2005, 21, 3674-3676. [CrossRef] [PubMed]

25. Li, L.; Stoeckert, C.J., Jr.; Roos, D.S. OrthoMCL: Identification of Ortholog Groups for Eukaryotic Genomes. Genome Res. 2003, 13, 2178-2189. [CrossRef] [PubMed]

26. Petersen, T.N.; Brunak, S.; von Heijne, G.; Nielsen, H. SignalP 4.0: Discriminating Signal Peptides from Transmembrane Regions. Nat. Methods 2011, 8, 785-786. [CrossRef]

27. Hulpiau, P.; van Roy, F. Molecular Evolution of the Cadherin Superfamily. Int. J. Biochem. Cell Biol. 2009, 41, 349-369. [CrossRef]

28. Jiang, R.H.Y.; Tripathy, S.; Govers, F.; Tyler, B.M. RXLR Effector Reservoir in two Phytophthora species is Dominated by a Single Rapidly Evolving Superfamily with more than 700 Members. Proc. Natl. Acad. Sci. USA 2008, 105, 4874-4879. [CrossRef]

29. Dou, D.; Kale, S.D.; Wang, X.; Jiang, R.H.Y.; Bruce, N.A.; Arredondo, F.D.; Zahng, X.; Tyler, B.M. RXLR-Mediated Entry of Phytophthora sojae Effector Avr1b into Soybean Cells does not Require Pathogen-Encoded Machinery. Plant Cell 2008, 20, $1930-1947$. [CrossRef]

30. Cantarel, B.L.; Coutinho, P.M.; Rancurel, C.; Bernard, T.; Lombard, V.; Henrissat, B. The Carbohydrate-Active EnZymes Database (CAZy): An Expert Resource for Glucogenomics. Nucleic Acids Res. 2009, 37, D233-D238. [CrossRef]

31. Zerillo, M.M.; Adhikari, B.N.; Hamilton, J.P.; Buell, C.R.; Lévesque, C.A.; Tisserat, N. Carbohydrate-Active Enzymes in Pythium and their Role in Plant Cell Wall and Storage Polysaccharide Degradation. PLoS ONE 2013, 8, e72572. [CrossRef]

32. Stamatakis, A. RAxML-VI-HPC: Maximum Likelihood-Based Phylogenetic Analyses with Thousands of Taxa and Mixed Models. Bioinformatics 2006, 22, 2688-2690. [CrossRef]

33. Tang, H.; Bowers, J.E.; Wang, X.; Ming, R.; Alam, M.; Paterson, A.H. Synteny and Collinearity in Plant Genomes. Science 2008, 320, 486-488. [CrossRef] [PubMed]

34. Ai, G.; Yang, K.; Ye, W.; Tian, Y.; Du, Y.; Zhu, H.; Li, T.; Xia, Q.; Shen, D.; Peng, H.; et al. Prediction and Characterization of RXLR Effectors in Pythium Species. Mol. Plant-Microbe Interact. 2020, 33, 1046-1058. [CrossRef] [PubMed]

35. Campion, C.; Massiot, P.; Rouxel, F. Aggressiveness and Production of Cell Wall Degrading Enzymes by Pythium violae, Pythium sulcatum and Pythium ultimum, Responsible for Cavity Spot on Carrots. Eur. J. Plant Pathol. 1997, 103, 725-735. [CrossRef]

36. Zerbino, D.R.; Birney, E. Velvet: Algorithms for de novo Short Read Assembly Using de Bruijn Graphs. Genome Res. 2008, 18, 821-829. [CrossRef]

37. Simpson, J.T.; Durbin, R. Efficient De Novo Assembly of Large Genomes Using Compressed Data Structures. Genome Res. 2012, 22, 549-556. [CrossRef]

38. van Dongen, S.M. Graph Clustering by Flow Simulation. Ph.D. Thesis, University of Utricht, Utricht, The Netherlands, 2000; p. 169. Available online: https:/ / dspace.library.uu.nl/bitstream/handle/1874/848/full.pdf?sequence=1 (accessed on 16 August 2020).

39. Katoh, K.; Misawa, K.; Kuma, K.; Miyata, T. MAFFT: A Novel Method for Rapid Multiple Sequence Alignment Based on Fast Fourier Transform. Nucleic Acid Res. 2002, 30, 3059-3066. [CrossRef]

40. Han, M.V.; Thomas, G.W.C.; Lugo-Martinez, J.; Hahn, M.W. Estimating Gene Gain and Loss Rates in the Presence of Error in Genome Assembly and Annotation Using CAFE3. Mol. Biol. Evol. 2013, 30, 1987-1997. [CrossRef]

41. Finn, R.D.; Coggill, P.; Eberhardt, R.Y.; Eddy, S.R.; Mistry, J.; Mitchell, A.L.; Potter, S.C.; Punta, M.; Qureshi, M.; Sangrador-Vegas, A. The Pfam Protein Families Database: Towards a More Sustainable Future. Nucleic Acid Res. 2016, 44, D279-D285. [CrossRef]

42. Mi, H.; Huang, X.; Muruganujan, A.; Tang, H.; Mills, C.; Kang, D.; Thomas, P.D. PANTHER version 11: Expanded Annotation Data from Gene Ontology and Reactome Pathways, and Data Analysis Tool Enhancements. Nucleic Acids Res. 2017, 45, D183-D189. [CrossRef]

43. Krogh, A.; Larsson, B.; von Heijne, G.; Sonnhammer, E.L.L. Predicting Transmembrane Protein Topology with a Hidden Markov Model: Application to Complete Genomes. J. Mol. Biol. 2001, 305, 567-580. [CrossRef] [PubMed]

44. Park, B.H.; Karpinets, T.V.; Syed, M.H.; Leuze, M.R.; Uberbacher, E. CAZymes Analysis Toolkit (CAT): Web Service for Searching and Analyzing Carbohydrate-Active Enzymes in a Newly Sequenced Organism using CAZy Database. Glycobiology 2010, 20, 1574-1584. [CrossRef] [PubMed]

45. Camacho, C.; Coulouris, G.; Avagyan, V.; Ma, N.; Papadopoulos, J.; Bealer, K.; Madden, T.L. BLAST+: Architecture and Applications. BMC Bioinform. 2009, 10, 421. [CrossRef] [PubMed]

46. Krzywinski, M.; Schein, J.; Birol, I.; Connors, J.; Gascoyne, R.; Horsman, D.; Jones, S.J.; Marra, M.A. Circos: An Information Aesthetic for Comparative Genomics. Genome Res. 2009, 19, 1639-1645. [CrossRef] [PubMed] 